\title{
Safety Documentation
}

\author{
for the M.I.C.E.
}

\section{2 slot VLPC Cryocooler Cryostat}

D-ZERO ENGINEERING NOTE \# 3823.000-EN-575

March 22, 2005

Author: Russell A. Rucinski

PPD/MD/D0 Operations 
Table of Contents

A. Partial Operational Readiness Clearance

a. Signed Form

b. Communications during review

B. Pressure Vessel Engineering note

C. Pressure Testing Permit 
Commissioning of 2 Slot VLPC cryostat for M.I.C.E.

Partial Operational Readiness Clearance

18 Feb 2005

AUTHORIZATION TO OPERATE COOL DOWN AND OPERATE CRYOCOOLER AND 2 SLOT CRYOSTAT

REVIEWED AND APPROVED BY:

particle Physics Division Head JIM STRAIT

Comments/Exceptions:

Martha Cf te

Particle Physics Division sent Safetrofficer

Comments/Exceptions

Q14imsbow Le Bah ers

Comments/Exceptions:
DATE

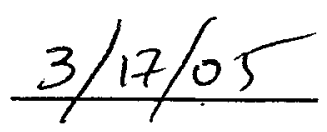

$3 / 16105$

$3 / 15 / 05$

Submitted By:

Russell A. Rucinski, ID \#8351

Feb. 18. 2005

[enter name]

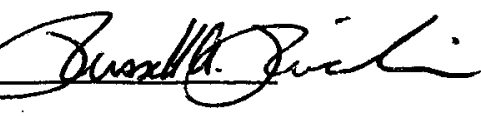


Fermi National Accelerator Laboratory Technical Division

E\&F Department

P.O. Box 500

Batavia, IL 60510

Mail Stop 343

Phone: (630)840-2458 Fax: (630) 840-8032

Tuesday, March 15, 2005

\author{
To: \\ Win Baker \\ Chairman, D0 ES\&H Review Committee \\ From: $\quad$ Harry Carter \\ Chairman, D0 Mechanical Safety Subcommittee \\ Subject: $\quad$ Review of the M.I.C.E. VLPC Cryostat at D0
}

Dear Win,

I have reviewed and signed off on the pressure vessel engineering note for the M.I.C.E. VLPC cryostat. While this vessel is considered to be an exceptional vessel requiring a director's exemption by the letter of the law (FESHM5031), the vessel has been designed and constructed using sound engineering practices, and it's pressure relief devices are appropriately sized such that operation of this vessel poses no hazard to equipment or personnel, thus I can recommend that a director's exemption be granted with no reservations.

I also visited D0 and inspected the cryostat and the test setup. Russ Rucinski, the responsible engineer, met with me and answered all questions that I had regarding the cryostat and the test plans. Based on that visit and my review, I have no reservations in recommending that a partial operational readiness clearance be granted for the commissioning and operation of the MICE VLPC Cryostat at D0.

Included with this memo are the original pressure vessel engineering note and the original pressure testing permit. Please see that they are routed to the proper personnel for the required signatures, then it is my understanding from Russ that they should be returned to him.

If you have any questions regarding my review or recommendations, please contact me at extension 2458 or via email: hfcarter@fnal.gov.

Best Regards,

Harry Carter 


\section{Fermilab}

Particle Physics Division, MD, D-Zero

TO: Win Baker, D0 ES\&H review committee

FROM: $\quad$ Russ Rucinski, PPD/MD/DZero Ops

SUBJECTS: pORC to operate M.I.C.E. VLPC cryostat at DZERO

Description of system

I am requesting a partial operational readiness clearance (pORC) to operate a small VLPC (visible light photon counter) cryostat system here at DZero.

We hope to be ready to operate the week of March 14th. It would be "commissioned" for both cryogenic operation and VLPC readout system in the weeks that follow. The working system will then be shipped to KEK for use in a test beam (May $24^{\text {th }}-$ July $2^{\text {nd }}$ ). This work is for the muon ionization cooling experiment (MICE).

The system consists of a commercially obtained cryocooler (Sumitomo Heavy Industries RD415 ) and a Fermilab designed 2 slot VLPC cryostat. The hazards associated with these items fall below the threshold that requires a rigorous formal review.

The cryocooler system utilizes a small cabinet size helium compressor with room temperature supply and return lines connected to the cryocooler head. There is also a power cable that links the two items. The cryocooler head is mounted in the center of the cryostat lid. There is no buffer tank or pressure vessel or liquid cryogens. (More information can be found on the SHI website: http://www.shicryogenics.com/products/?id=6496 )

The 2 slot cryostat was uniquely designed by me to provide cooling of the VLPC chips that are packaged in the bottom of a cassette. A separate file is attached which contatins pictures and a description. The envelopes (or pockets) that the cassette slip into are filled with gas helium at a slightly positive pressure to provide a heat transfer medium and to prevent potential contamination. There is an insulating vacuum on the outside of the envelopes. Technically, since the envelope has a dimension that exceeds 6", the envelopes are considered a pressure vessel if the differential pressure across the wall is greater than 15 psid. The average barometric pressure for Fermilab is $740 \mathrm{mmHg}=14.3$ psia so at a helium operating pressure greater than $0.7 \mathrm{psig}$, the envelope technically becomes a pressure vessel per FESHM5031.

I plan to operate in the range of $1.5+/-0.5$ psig with redundant relief valves set at $2.0 \mathrm{psig}$. This is based on operational experience with previous VLPC cryostats. Therefore a pressure vessel engineering is required (separate file attached). It must be noted that the envelope's 
stored potential energy is neglible (less than 180 joules). The usual threshold used is the product of the pressure times volume. For instance for the other FESHM vessel standards, if $\mathrm{P}^{*} \mathrm{~V}>515 \mathrm{psi}-\mathrm{ft}^{\wedge} 3$ a low pressure vessel engineering note (FESHM 5031.5) or vacuum vessel engineering note (FESHM 5033) is required. If $\mathrm{P}^{*} \mathrm{~V}<515 \mathrm{psi}-\mathrm{ft}^{\wedge} 3$ then the vessel is excluded from requiring formal documentation. In the case of the 2 slot VLPC cryocooler cryostat, the total empty volume is only $0.3 \mathrm{ft}^{\wedge} 3$ and $\mathrm{P}^{*} \mathrm{~V}=(16.3 \mathrm{psid})^{*}\left(0.3 \mathrm{ft}^{\wedge} 3\right)=5 \mathrm{psi}-\mathrm{ft}^{\wedge} 3$. A similar exclusion for FESHM 5031.1 should be entertained.

Because of the unique design, a pressure vessel engineering note needs a director's exemption. This is because ASME code relief valves cannot be obtained for pressures less than 15 psig, and the vessel uses a non-code material, invar 36. While the potential risk of operating this vessel does not justify time and effort in documentation, the safety review process requires it.

Sincerely, 
Date: Thu, 03 Mar 2005 15:52:13-0600

From: Harry Carter <hfcarterefnal.gov>

To: Win baker <winbakerefnal.gov>

Cc: Russ Rucinski <rucinskiefnal.gov>

Subject: RE: pORC request for DZero/M.I.C.E. VLPC test stand (fwd)

Hi Win,

I met with Russ at Do a little while ago to review the system

before he got away on vacation. I do not see any show stoppers

here, but will review the documentation in a little more detail

before issuing a formal letter to you and signing off on the

Pressure Vessel note. Russ gave me the original of the note,

which I will send to you along with my letter, unless you would

prefer that it be sent directly to the PPD Division office.

Just thought I would give you a heads up on the status of things.

Regards,

Harry

-----Original Message-----

From: Win baker [mailto:winbakerefnal.gov]

Sent: Thursday, March 03, 2005 10:02 AM

To: hfcarterefnal.gov

Cc: tomskiefnal.gov; wandsefnal.gov; rucinskiefnal.gov; marthaefnal.gov;

rpsmithefnal.gov; straitefnal.gov; winbakereimapserver2.fnal.gov

subject: $F W$ : pORC request for DZero/M.I.C.E. VLPC test stand (fwd)

Hi Harry,

It's been a while, but Dzero is still there and hopefully our committee also.

Following is Russ Rucinski's request for a review of a new system. He suggests times for an inspection.

Best regards

When you contact him please cc me as usual. Thanks.

Win

$>$ - - - - - Forwarded message -- - - - -

$>$ Date: Wed, 02 Mar 2005 12:38:05-0600

$>$ From: Russell Rucinski <rucinskiefnal.gov>

$>$ To: Win Baker <winbakerefnal.gov>

$>$ Cc: Martha Heflin <marthaefnal.gov>, Jim strait <straitefnal.gov>, Richard P. Smith <rpsmithefnal.gov>

Subject: pORC request for DZero/M.I.C.E. VLPC test stand

$>$ Hi Win,

Please see the attached files.

'Request for pORC for 2 slot' is the formal memo requesting approval to operate a new system at DZERO for a few weeks of commisioning.

$>$

$>$ '2slotPVen.doc' is a pressure vessel engineering note. It requires a independent review and then a director's exemption. Due to it's neglible stored energy, a note is required by technicality only. Hopefully the review process will be trivial as all involved will recognize this. $>$

$>$ 'PORC form 2slot' is the completed pORC form usually used for signatures.

$>$ The power point file 'Cryocooler Cryostat Design overview.pps' is an overview presentation of the cryostat that I pieced together from previous presentations.

$>$ We would like to operate sometime around March 16 th or shortly thereafter.

$>$ It would be most efficient for the reviewer (Do Mechanical subcommittee? Harry Carter?) to come out to Dzero to see the setup. I am here today and tommorrow March 3rd. Due to scheduled vacation I will be unavailable Friday March $4 \mathrm{th}$ or the week of March 7.th. If a walk thru is desired during my absence, Jim Eagan is the contact person. We could also do it on March 14 th.

$>$

$>$ Thank you. 
$>$ Russ Rucinski

$>$

$>$

$>$ P.S. Jim Strait and Martha Heflin are cc'd on this since they requested that it go through formal channels for sign off.

$$
>
$$


Tuesday, March 15, 2005

To:

Win Baker

Chairman, D0 ES\&H Review Committee

From:

Harry Carter

Chairman, D0 Mechanical Safety Subcommittee

Subject:

Review of the M.I.C.E. VLPC Cryostat at D0

Dear Win,

I have reviewed and signed off on the pressure vessel engineering note for the M.I.C.E. VLPC cryostat. While this vessel is considered to be an exceptional vessel requiring a director's exemption by the letter of the law (FESHM5031), the vessel has been designed and constructed using sound engineering practices, and it's pressure relief devices are appropriately sized such that operation of this vessel poses no hazard to equipment or personnel, thus I can recommend that a director's exemption be granted with no reservations.

I also visited D0 and inspected the cryostat and the test setup. Russ Rucinski, the responsible engineer, met with me and answered all questions that I had regarding the cryostat and the test plans. Based on that visit and my review, I have no reservations in recommending that a partial operational readiness clearance be granted for the commissioning and operation of the MICE VLPC Cryostat at D0.

Included with this memo are the original pressure vessel engineering note and the original pressure testing permit. Please see that they are routed to the proper personnel for the required signatures, then it is my understanding from Russ that they should be returned to him.

If you have any questions regarding my review or recommendations, please contact me at extension 2458 or via email: hfcarter@fnal.gov.

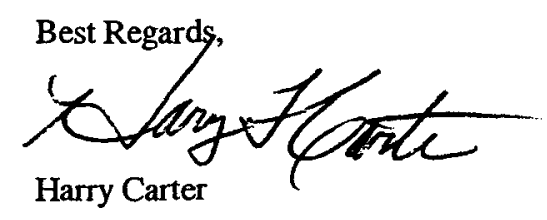




\section{PRESSURE VESSEL ENGINERING NOTE \\ PER CHAPTER 5031}

Prepared by:

Russ Rucinski, PPD/MD/DZERO Ops

Preparation date: Feb. 14, 2005

1. Description and Identification

Fill in the label information below:

This vessel DOES NOT CONFORM to Fermilab ES\&H Manual Chapter 5031

Vessel Title 2 slot VLPC cryo cooler cryostat -

Vessel Number Not applicable: for use at KEK -

Vessel Drawing Number 3823.111-me-434117

Maximum Allowable Working Pressures (MAWP):

Internal Pressure $2 \mathrm{psig}+$ full vacuum $(16.7 \mathrm{psid})$

External Pressure none

Working Temperature Range $-452 \mathrm{~F}$ to $100 \mathrm{~F}$

Contents Gaseous Helium

Designer/Manufacturer Fermilab, Russ Rucinski

Test Pressure (if tested at Fermi) Date: $3 / 3 / 05$

4_PSIG, Hydraulic _ Pneumatic $\underline{\mathbf{x}}$ - GHe

Accepted as conforming to standard by

of Division/Section

Date:

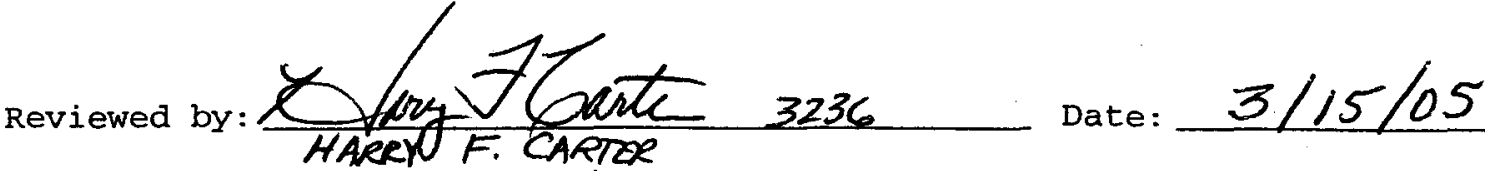
Director's signature (or designee) if the vessel is for manned areas but doesn't conform to the requirements of the chapter.

Date: 
Lab Property Number (s) : Not Applicable

Lab Location Code: $N / A$ for use at KEK (obtain from safety officer) Purpose of Vessel(s):

\section{Contains gas helium and VLPC cassettes operating at $9 \mathrm{~K}$.}

Vessel Capacity/Size: 2 volumes, each 1.45 inches $x 10.5$ inches $x 16.8$ inches Normal Operating Pressure (OP) 1.5 PSIG + fuII vacuum $=16.2$ psid

MAWP-OP $=$

List the numbers of all pertinent drawings and the location of the originals. Drawing \# Location of Original

3823.111-ME-434.117 DZFRO Assembly Building Highbay drg. Files

(Electronically stored in lab's drawing control system)

2. Design Verification

Is this vessel designed and built to meet the Code or "In-House Built" requirements?

Yes___ No_ $\mathbf{x}_{\text {_. }}$.

If "No" state the standard that was used:

Engineering stress and deflegtion calculations with stresses were kept below an ASME code, Section fly Div. 2 derived allowable stress for Invar 36 (34 ksi for local bending stress). A design pressure of 21 psid was used for calculation of stresses. MAWP is 16.7 psid. Along with good engineering practice, I used Roark's Formulas for stress \& strain, $6^{\text {th }}$ edition, edited by Warren C. Young. Material certifications for the materials were obtained.

Demonstrate that design calculations of that standard have been made and that other requirements of that standard have been satisfied.

Skip to part 3 "system venting verification."

Does the vessel(s) have a U stamp? Yes No_X_. If "Yes", complete section 2A; if "No", complete section 2B. 
Provide ASME design calculations in an appendix. On the sketch below, circle all applicable sections of the ASME code per section VIII, Division I. (Only for non-coded vessels)

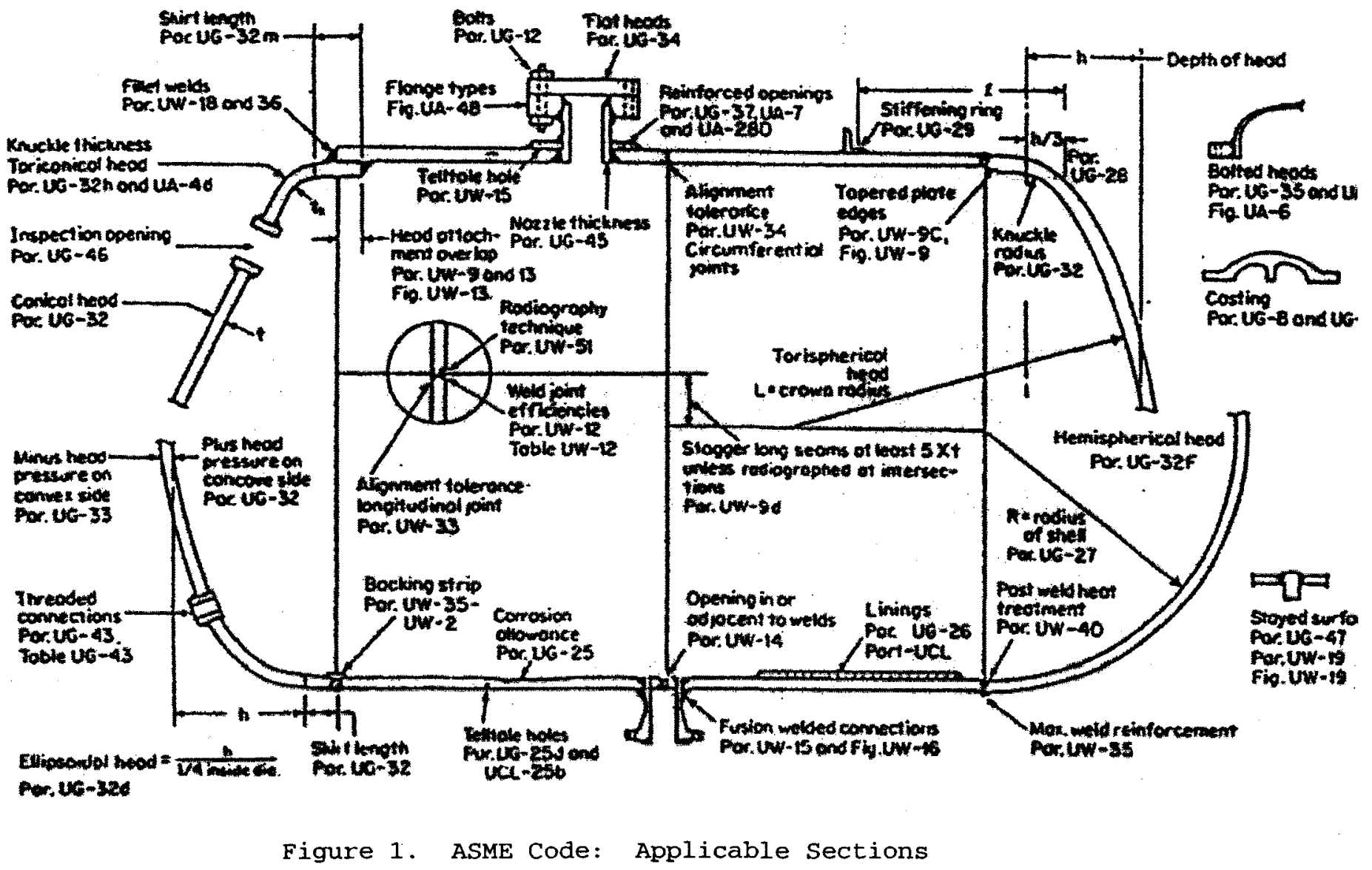

2B.

Summary of ASME Code

Item $\quad \begin{aligned} & \text { Reference Asm } \\ & \text { Code Section }\end{aligned}$

Reference ASME

section
CALCULATION RESULT

(Required thickness or stress level vs. actual thickness calculated stress level) 
Provide ASME design calculations in an appendix. On the sketch below, circle all applicable sections of the ASME code per section VIII, Division I. (Only for non-coded vessels)

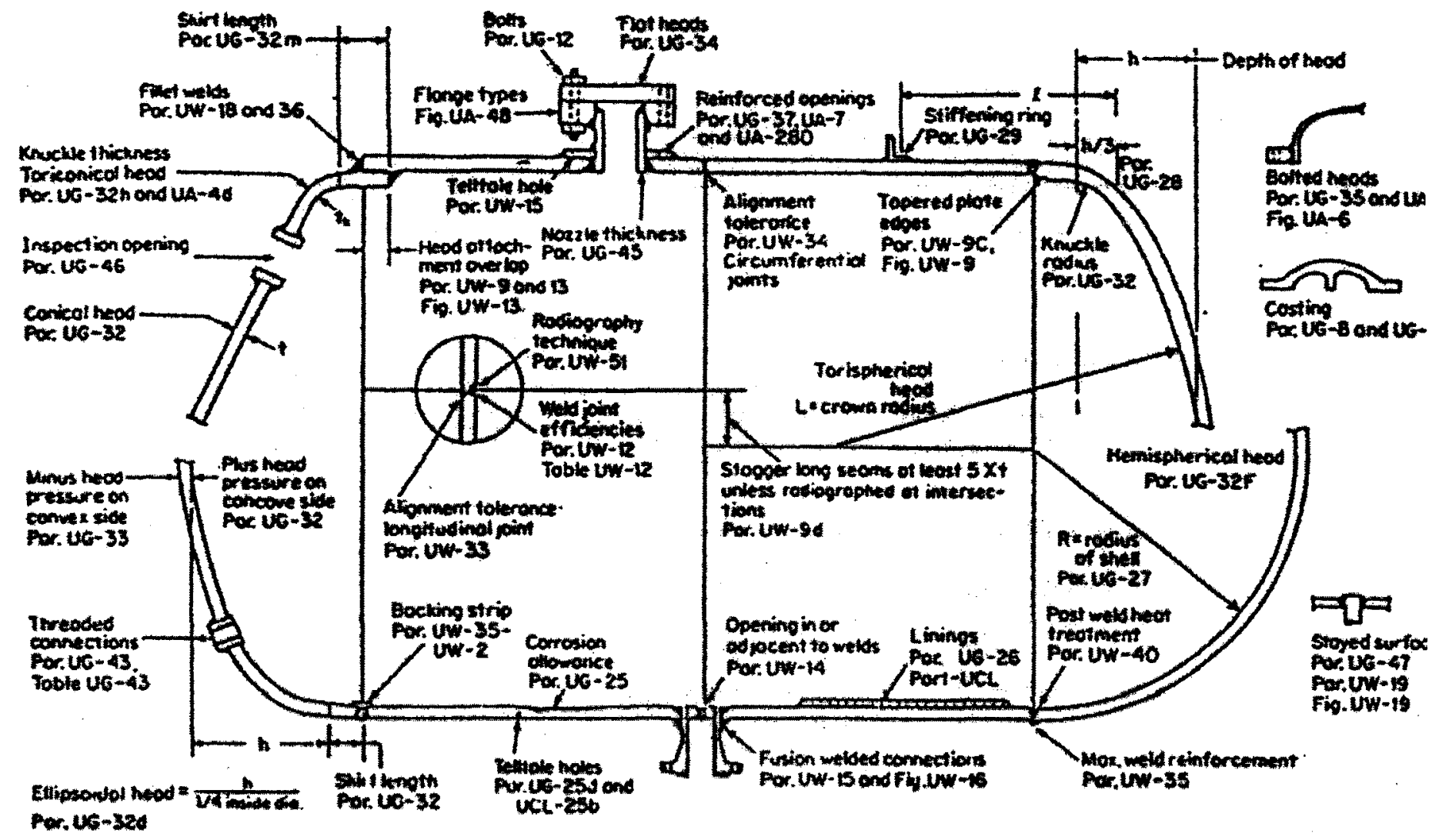

Figure 1. ASME Code: Applicable Sections

2B.

Summary of ASME Code

Item $\begin{aligned} & \text { Reference ASME } \\ & \text { code Section }\end{aligned}$

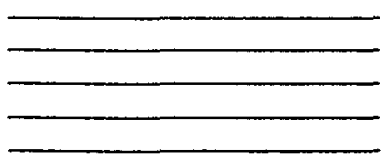

Reference ASME

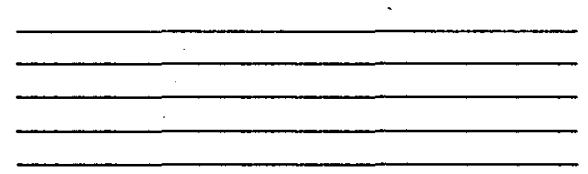

CALCULATION RESULT

(Required thickness or stress level vs. actual thickness calculated stress level) 
3. System Venting Verification Provide the vent system schematic.

Does the venting system follow the Code UG-125 through UG-137?

Yes__ No_x_ (Non ASME coded relief)

Does the venting system also follow the Compressed Gas Association Standards $\mathrm{S}-1.1$ and $\mathrm{S}-1.3$ ?

Yes _ No_ $x_{-}$(Non ASME coded relief)

A "no" response to both of the two proceeding questions requires a justification and statement regarding what standards were applied to verify system venting is adequate.

ASME code valves are not available < 15 psig set point. Required flow rate for loss of vacuum $=0.3 \mathrm{scfm}$. No other source of overpressurization is applicable. The gas supply line is connected upstream of the relief device and tubing size is less than relief size.

Note that stored energy of the vessel is negligible. vessel is contained within a vacuum jacket as well. Volume $x$ Pressure $=5$ psigft^3. Threshold used for review is 535 psig-ft^3. At 4 psig test pressure there is only 182 Joules of stored potential energy. This is probably less stored energy than that in a 2 liter bottle of soda pop.

List of reliefs and settings:

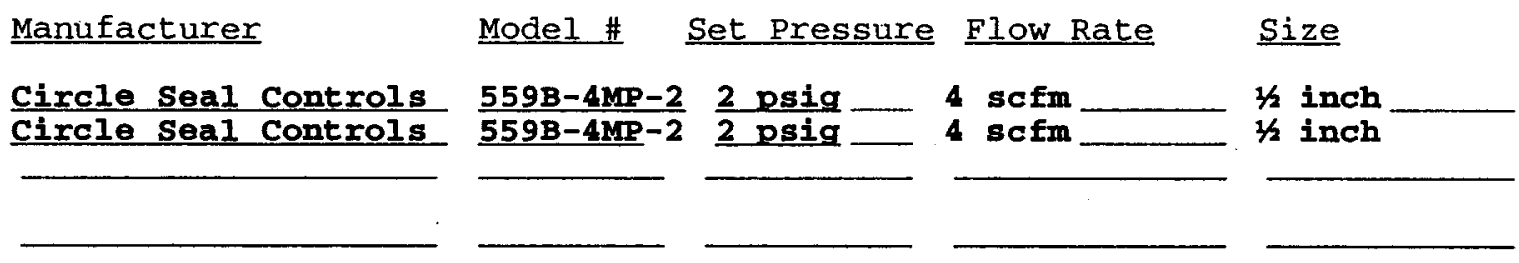

4. Operating Procedure

Is an operating procedure necessary for the safe operation of this vessel? Yes___ No_x__ (If "Yes", it must be appended)

No procedure is required for personnel safety. A procedure/precaution is only necessary to prevent possible mechanical or monetary damages.

Envelope must never be evacuated without vacuum container also evacuated to an equal or lesser pressure. Warning label applied directly to vessel.

5. Welding Information

Has the vessel been fabricated in a non-code shop? Yes_x_ No If "Yes", append a copy of the welding shop statement of welder qualification (Procedure Qualification Record, $P Q R$ ) which references the Welding Procedure Specification (WPS) used to weld this vessel.

6. Existing, Used and Unmanned Area Vessels

Is this vessel or any part thereof in the above categories? Yes__ No__ $\mathbf{x}$ 
If "Yes", follow the requirements for an Extended Engineering Note for Existing, Used and Unmanned Area Vessels.

7. Exceptional Vessels

Is this vessel or any part thereof in the above category? Yes_ $\mathbf{x}$ No

If "Yes", follow the requirements for an Extended Engineering Note for Exceptional Vessels. 


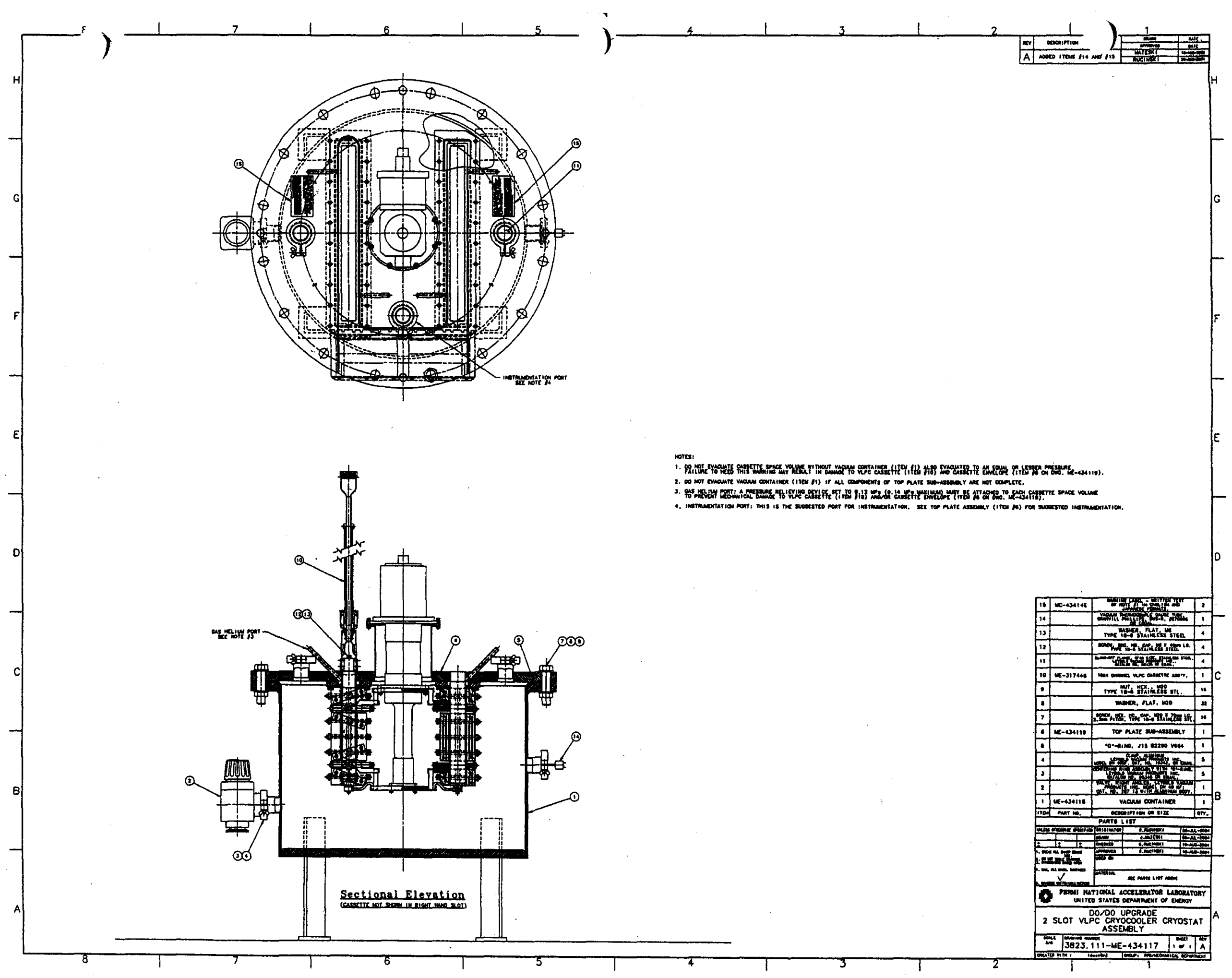




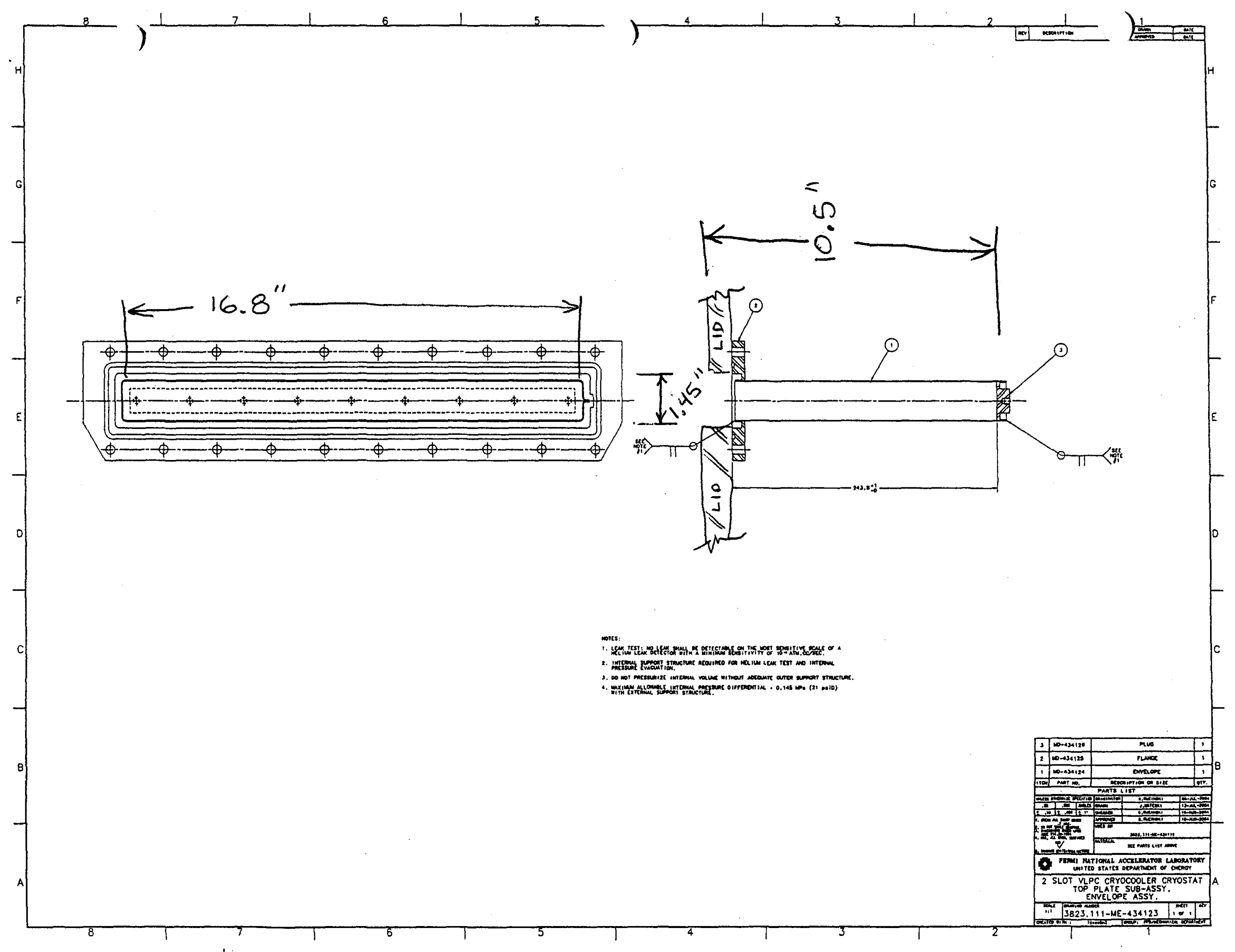




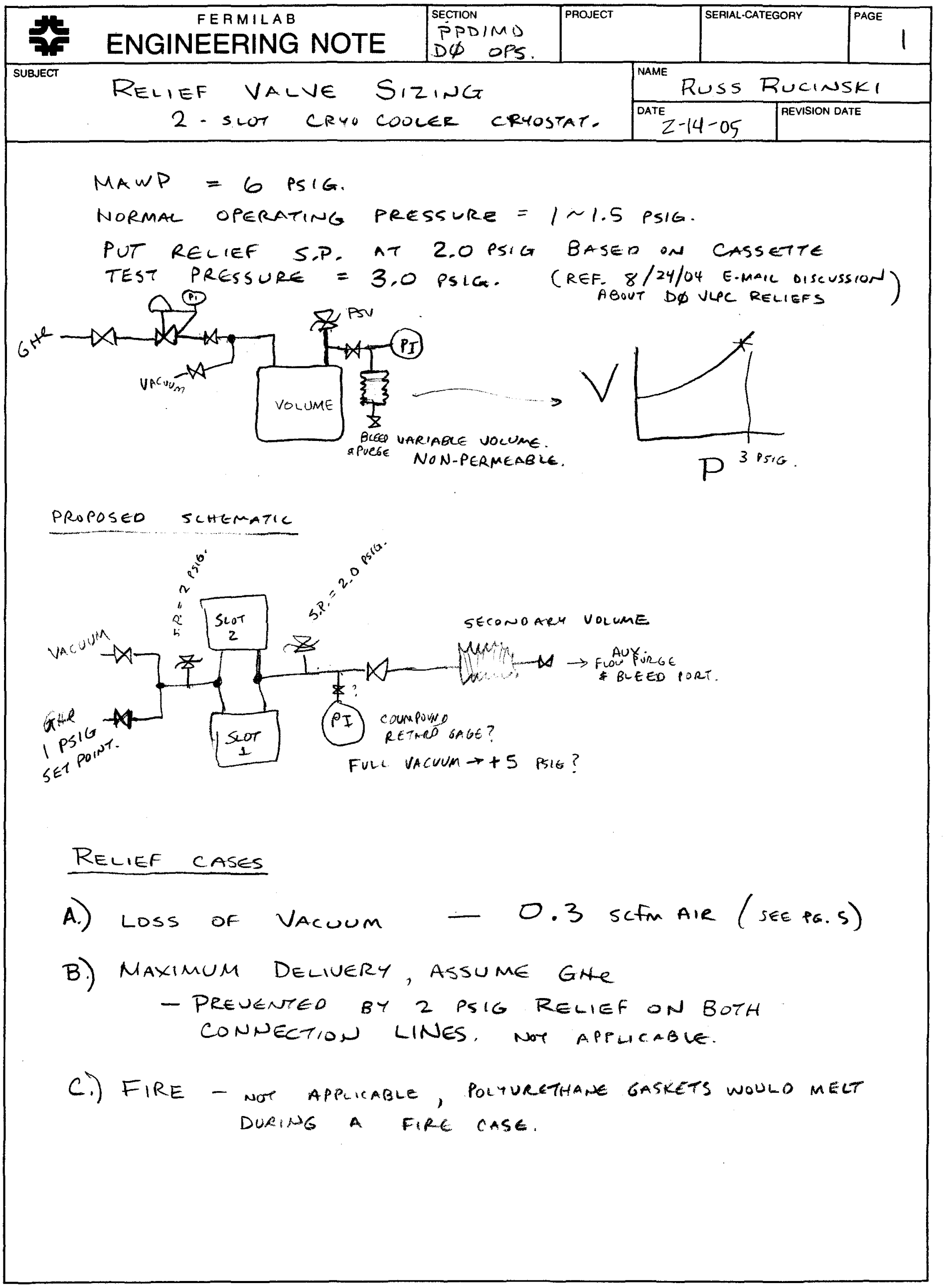




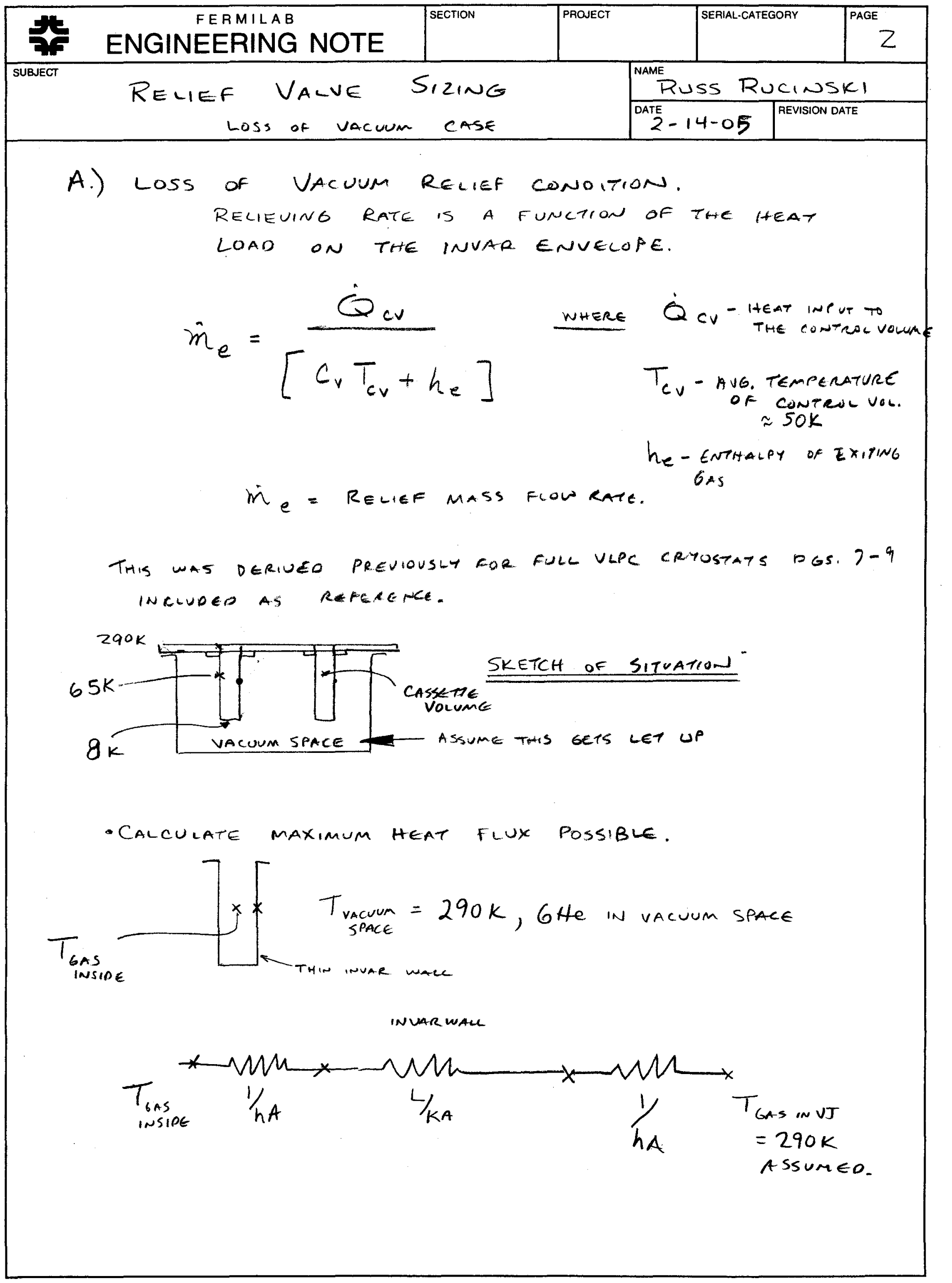


ENGINEERING NOTE

SECTION

PROJECT

SERIAL-CATEGORY

PAGE

SUBJECT

Relief valve sizing

Loss of vacuUM case

NAME

3

Russ Rucinsik1

DATE

REVISION DATE

OUTSIDE SURFACE

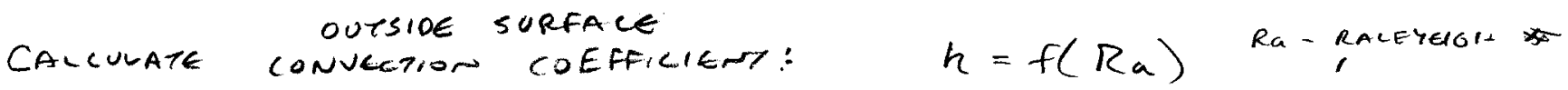

$$
\begin{aligned}
& R_{a}=\frac{g B\left(T_{s}-T_{\infty}\right) L^{3}}{\nu^{2}} \operatorname{Pr} \quad \text { LET } T_{s}=50 \mathrm{~K} T_{\infty}=290 \\
& =\frac{9.81 \mathrm{~m} / \mathrm{s}=\left(\frac{1}{170 \mathrm{~K}}\right)(290-50)(.25 \mathrm{~m})^{3}}{\left(130 \times 10^{-6} \mathrm{~m}^{2} / \mathrm{s}\right)^{2}}(0.66)
\end{aligned}
$$

$$
\begin{aligned}
& R_{a}=1100 \\
& R_{a} \ll 10^{9} \therefore \text { Lamirare flow } \\
& \overline{N u}_{L}=\frac{\hbar L}{K}=\frac{4}{3}\left(\frac{G r_{L}}{4}\right)^{\prime 4} g\left(P_{r}\right)
\end{aligned}
$$

w ${ }^{\prime} \in$ Re

$$
\begin{aligned}
& g\left(P_{r}\right)=\frac{.75 P_{r}^{1 / 2}}{\left(.609+1.221 P_{r}^{1 / 2}+1.238(r)^{1 / 4}\right.} \\
& \text { EQ. } 9,20 \\
& g\left(P_{r}\right)=.49 \quad G_{r_{L}}=\frac{R_{a}}{P_{r}}=\frac{1100}{-66}=1667 \\
& \overline{N u}_{L}=\frac{4}{3}\left(\frac{1667}{4}\right)^{1 / 4}(.49)=3.0= \\
& \bar{h}=\overline{N u} K / c=(3.0) \frac{(.10 \mathrm{w} / \mathrm{m}-\mathrm{K})}{.25 \mathrm{~m}}=1.2 \mathrm{w} / \mathrm{m}^{2} \mathrm{~K} \text {. } \\
& \text { A with god. } \\
& \text { But it is cons He. }
\end{aligned}
$$

assume inner convector n coEfFicient is the same. (conservative since $T_{5}-T_{0}$ will be cower)

$$
h_{\text {INNER }} \simeq 1.2 \mathrm{w} / \mathrm{m}^{2} \mathrm{~K} \quad \text { (Acruntity win se cess) }
$$




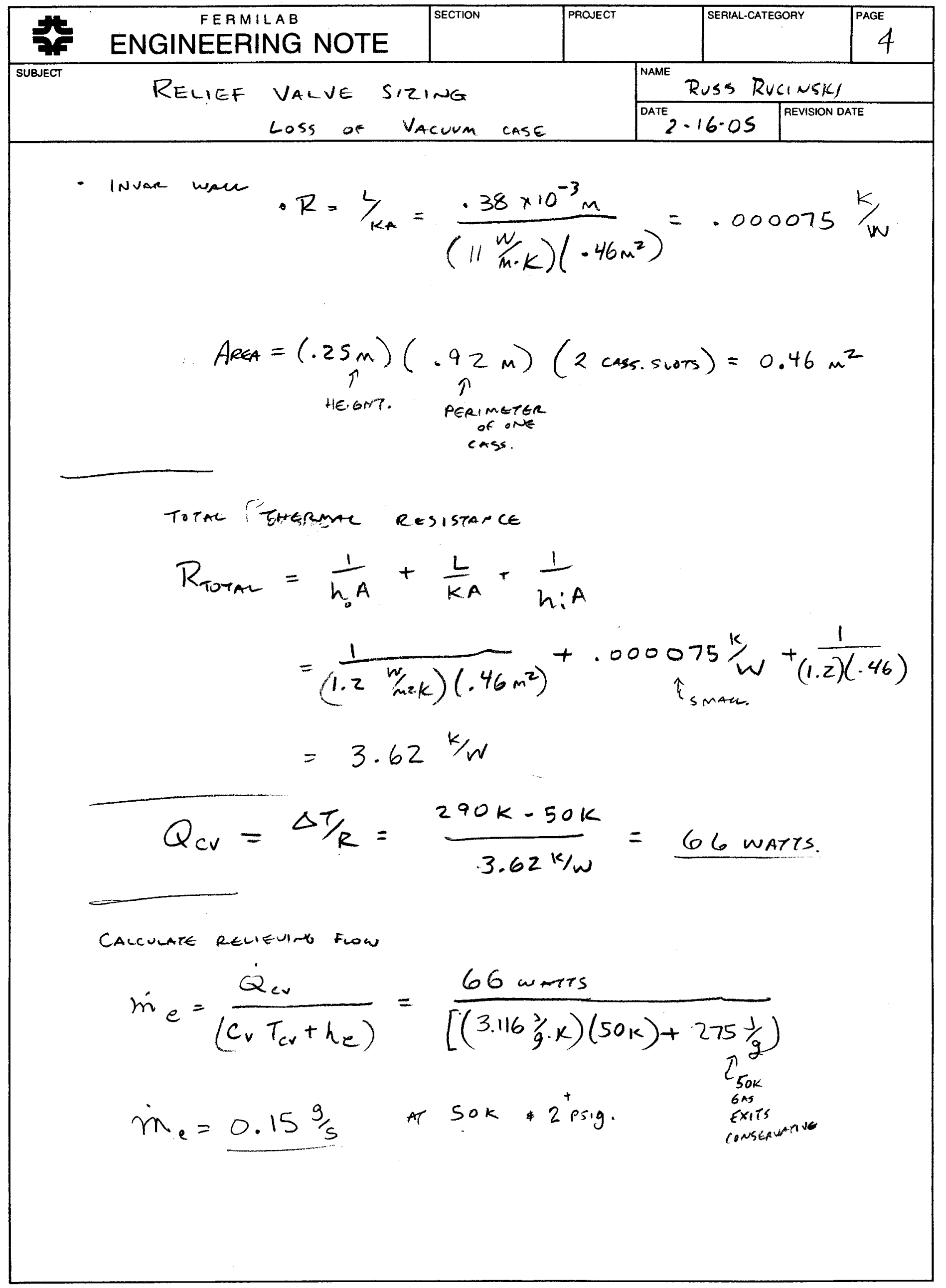




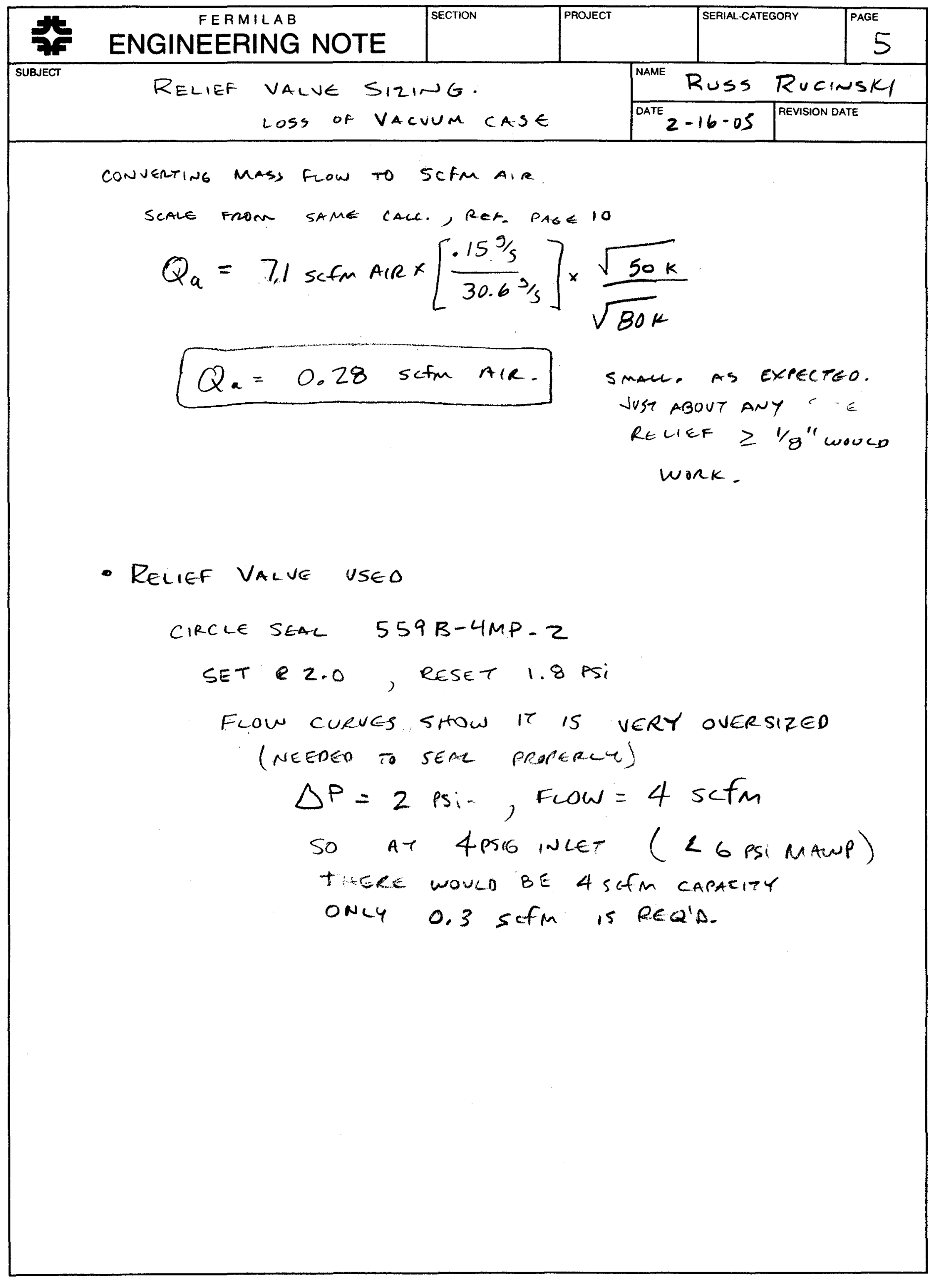




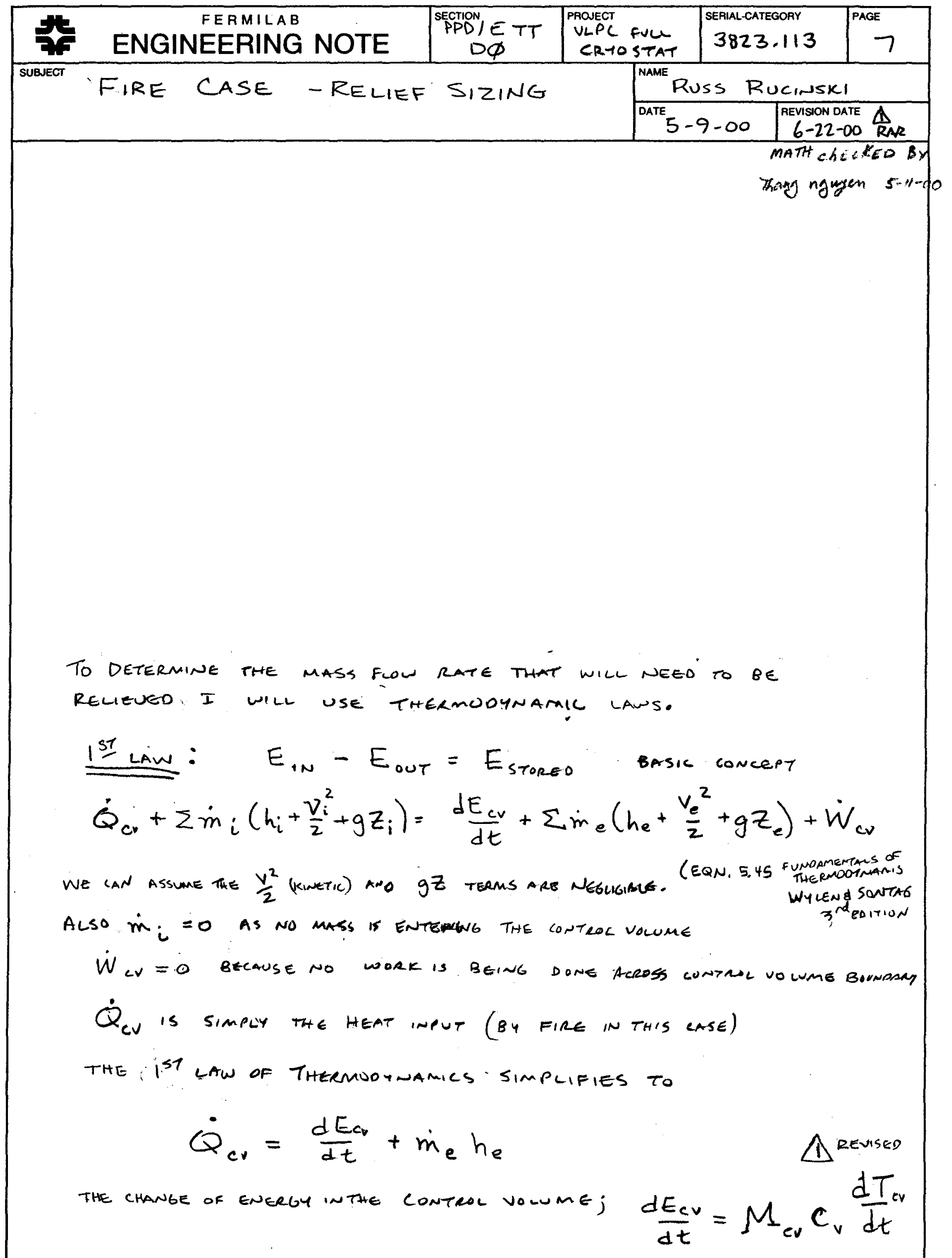




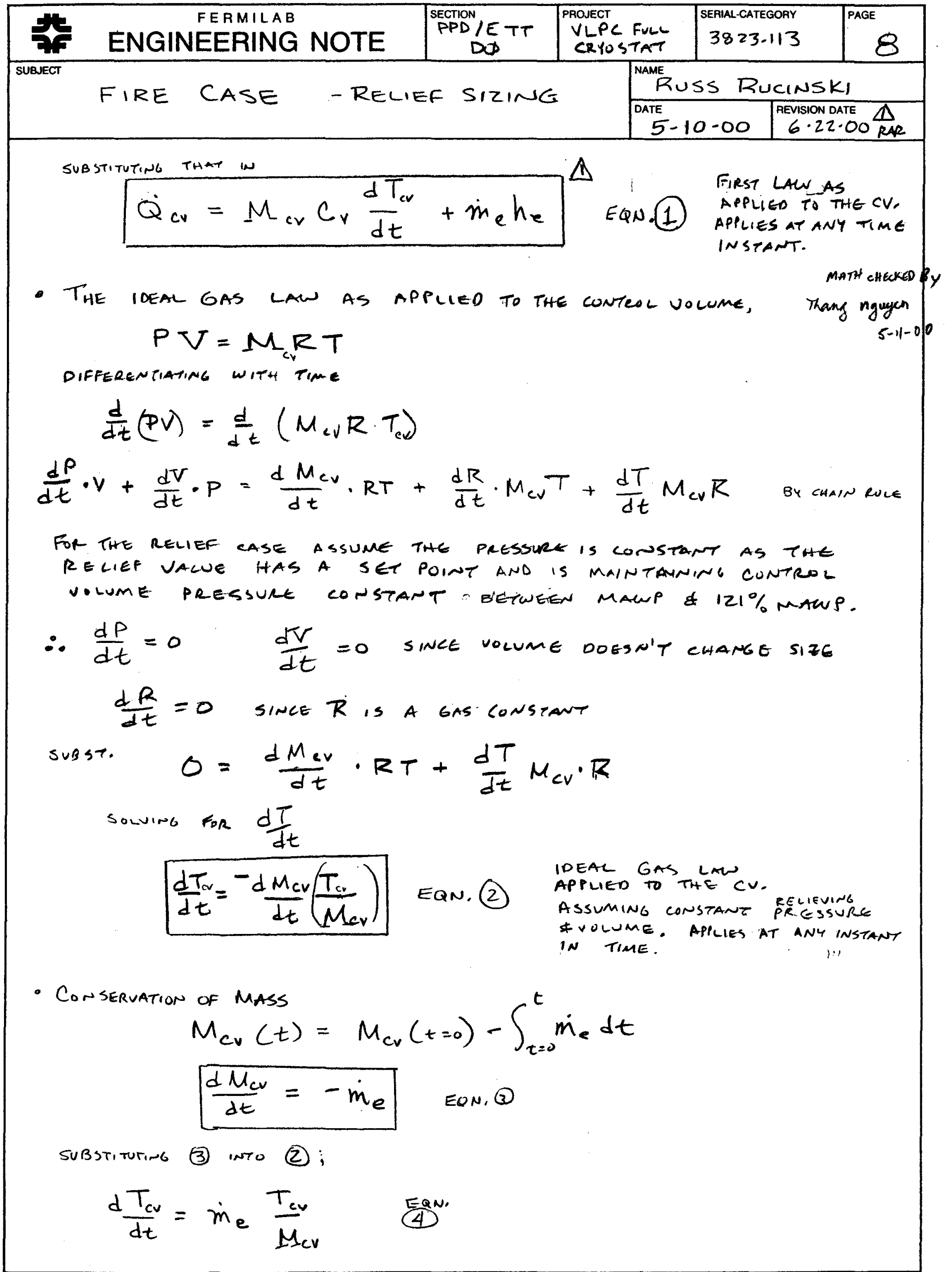




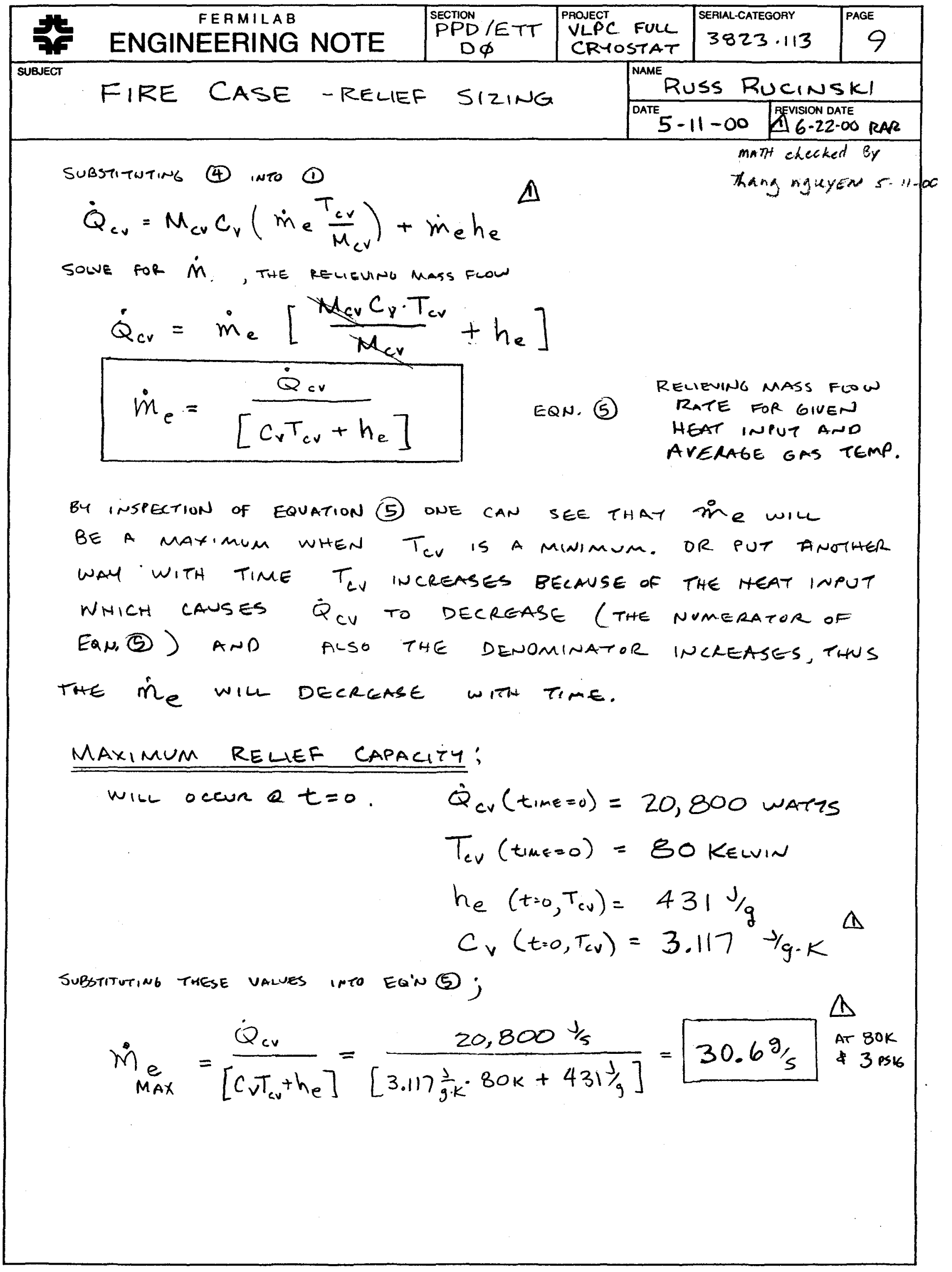




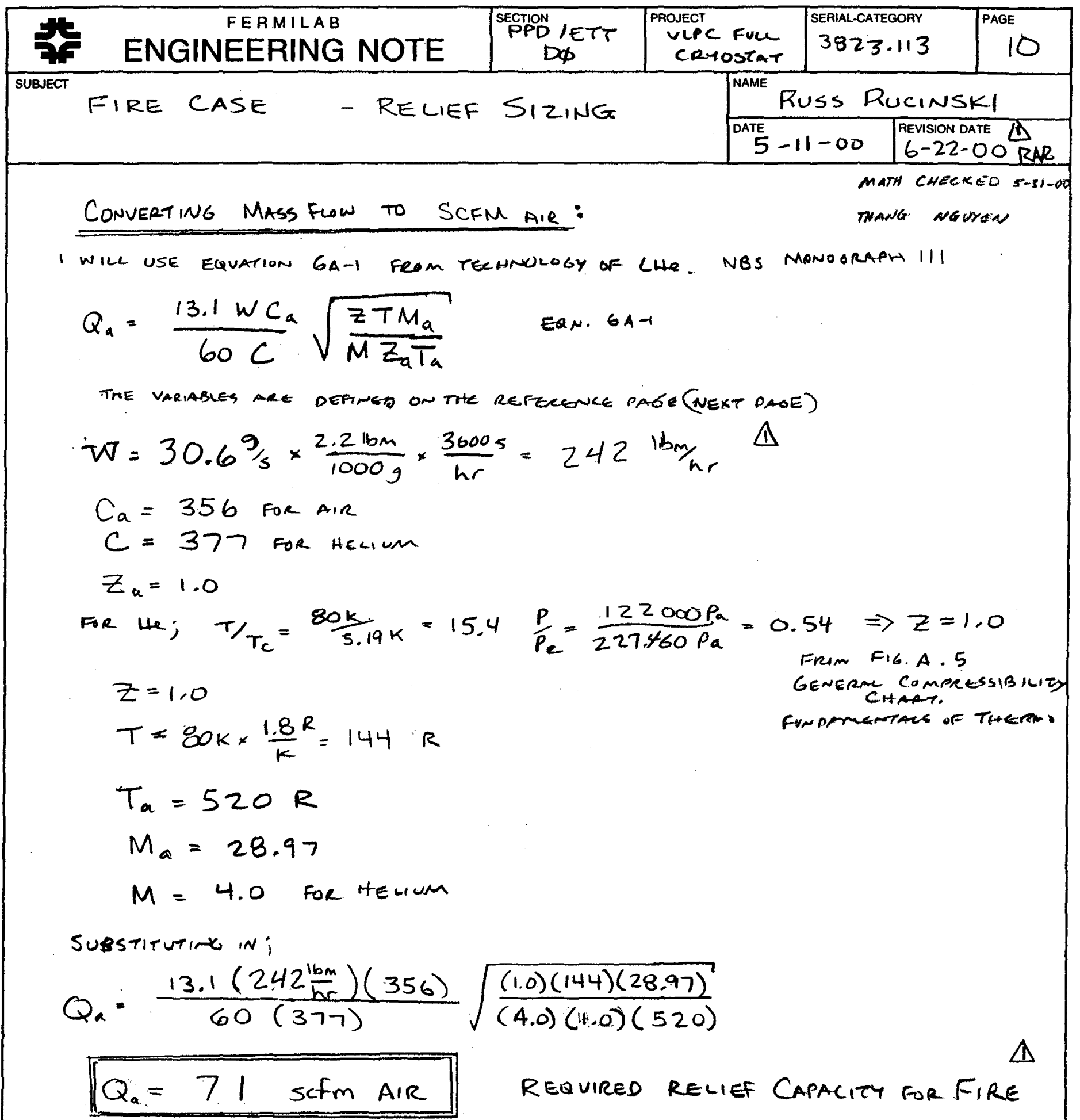




\section{APPENDIX A. SIZING OF RELIEF DEVICES}

The Compressed Gas Association [19] provides information for sizing of relief devices for compressed gases, including pressurized liquid oxygen, nitrogen, and argon and liquefied hydrogen, in cargo, portable, and storage tanks. A value of $G_{i}$ (the parameter used to size relief devices) is listed for each commodity and is dependent on the latent heat of vaporization and other physical properties of the specific fluid.

Sizing of relief devices for liquid helium containers is somewhat more complex, since the relieving pressure is usually above the critical pressure where no latent heat value exists. A method for handling helium is presented herein, a $G_{i}$ value being computed in typical fashion, but based on $L^{\prime}$, an equivalent value used in place of the latent heat of vaporization. The units of $L^{\prime}$ are Btu/bb, where Btu's represent the total heat added to the vapor between temperatures $T_{1}$ and $T_{x}$ per pound of efflux gas leaving the container at constant pressure, $P$. The $L^{\prime}$ varies significantly with $T_{x}$, and has its lowest value shortly after start of relief.

\section{Sixing for Fire Condition}

The basic equation for sizing relief devices is

$$
Q_{a}=\frac{13.1 W C_{a}}{60 C}\left(\frac{Z T M_{a}}{M Z_{a} T_{a}}\right)^{1 / 2}
$$

where $Q_{a}=\operatorname{scfm}$ of air at $520 \mathrm{R}(289 \mathrm{~K})$ and $14.7 \mathrm{psia}$, required capqcity of the relief device

$W=\mathrm{lb} / \mathrm{hr}$, required flow of the gas

$C_{a}=$ Gas constant $=356$ for air

$C=$ Gas constant of the gas

$Z_{a}=$ Compressibility factor $=1.0$ for air at STI

$Z=$ Compressibility factor for the gas at the fluw condition

$M_{a}=$ Molecular weight of air $=28.97$

$M=$ Molecular weight of the gas

$T_{a}=$ Temperature of air at STP $=520 \mathrm{R}$

$T=$ Temperature of the gas at the flow condition. 
Table A.4 Continued

\begin{tabular}{|c|c|c|c|c|c|c|c|}
\hline $\begin{array}{l}T \\
(\mathrm{~K})\end{array}$ & $\begin{array}{l}\rho \\
\left(\mathrm{kg} / \mathrm{m}^{3}\right)\end{array}$ & $\left(\mathrm{kJ} / \mathrm{kg}_{\mathrm{p}}^{c_{p}} \cdot \mathrm{K}\right)$ & $\begin{array}{l}\mu \cdot 10^{7} \\
\left(\mathrm{~N} \cdot \mathrm{s} / \mathrm{m}^{2}\right)\end{array}$ & $\begin{array}{l}10^{6} \\
\left(\mathrm{~m}^{2} / \mathrm{s}\right)\end{array}$ & $\begin{array}{c}k \cdot 10^{3} \\
(\mathrm{~W} / \mathbf{m} \cdot \mathrm{K})\end{array}$ & $\begin{array}{l}\alpha \cdot 10^{6} \\
\left(\mathrm{~m}^{2} / \mathrm{s}\right) \\
\end{array}$ & $\operatorname{Pr}$ \\
\hline \multicolumn{8}{|c|}{ Helium (He) } \\
\hline 100 & 0.4871 & 5.193 & 96.3 & 19.8 & 73.0 & 28.9 & 0.686 \\
\hline 120 & 0.4060 & 5.193 & 107 & 26.4 & 81.9 & 38.8 & 0.679 \\
\hline 140 & 0.3481 & 5.193 & 118 & 33.9 & 90.7 & 50.2 & 0.676 \\
\hline 160 & - & 5.193 & 129 & - & $99.2^{t}$ & - & - \\
\hline 180 & 0.2708 & 5.193 & 139 & 51.3 & 107.2 & 76.2 & 0.673 \\
\hline 200 & - & 5.193 & 150 & - & 115.1 & - & - \\
\hline 220 & 0.2216 & 5.193 & 160 & 72.2 & 123.1 & 107 & 0.675 \\
\hline 240 & - & 5.193 & 170 & - & 130 & - & - \\
\hline 260 & 0.1875 & 5.193 & 180 & 96.0 & 137 & 141 & 0.682 \\
\hline 280 & - & 5.193 & 190 & - & 145 & - & - \\
\hline 300 & 0.1625 & 5.193 & 199 & 122 & 152 & 180 & 0.680 \\
\hline 350 & - & 5.193 & 221 & - & 170 & - & - \\
\hline 400 & 0.1219 & 5.193 & 243 & 199 & 187 & 295 & 0.675 \\
\hline 450 & & 5.193 & 263 & - & 204 & - & - \\
\hline 500 & 0.09754 & 5.193 & 283 & 290 & 220 & 434 & 0.668 \\
\hline 550 & - & 5.193 & - & - & - & - & - \\
\hline 600 & - & 5.193 & 320 & - & 252 & - & - \\
\hline 650 & - & 5.193 & 332 & - & 264 & - & - \\
\hline 700 & 0.06969 & 5.193 & 350 & 502 & 278 & 768 & 0.654 \\
\hline 750 & - & 5.193 & 364 & - & 291 & - & - \\
\hline 800 & - & 5.193 & 382 & - & 304 & - & - \\
\hline 900 & - & 5.193 & 414 & - & 330 & - & - \\
\hline 1000 & 0.04879 & 5.193 & 446 & 914 & 354 & 1400 & 0.654 \\
\hline \multicolumn{8}{|c|}{ Hydrogen $\left(\mathrm{H}_{2}\right)$} \\
\hline 100 & 0.24255 & 11.23 & 42.1 & 17.4 & 67.0 & 24.6 & 0.707 \\
\hline 150 & 0.16156 & 12.60 & 56.0 & 34.7 & 101 & 49.6 & 0.699 \\
\hline 200 & 0.12115 & 13.54 & 68.1 & 56.2 & 131 & 79.9 & 0.704 \\
\hline 250 & 0.09693 & 14.06 & 78.9 & 81.4 & 157 & 115 & 0.707 \\
\hline 300 & 0.08078 & 14.31 & 89.6 & 111 & 183 & 158 & 0.701 \\
\hline 350 & 0.06924 & 14.43 & 98.8 & 143 & 204 & 204 & 0.700 \\
\hline 400 & 0.06059 & 14.48 & 108.2 & 179 & 226 & 258 & 0.695 \\
\hline 450 & 0.05386 & 14.50 & 117.2 & 218 & 247 & 316 & 0.689 \\
\hline 500 & 0.04848 & 14.52 & 126.4 & 261 & 266 & 378 & 0.691 \\
\hline 550 & 0.04407 & 14.53 & 134.3 & 305 & 285 & 445 & 0.685 \\
\hline 600 & 0.04040 & 14.55 & 142.4 & 352 & 305 & 519 & 0.678 \\
\hline 700 & 0.03463 & 14.61 & 157.8 & 456 & 342 & 676 & 0.675 \\
\hline 800 & 0.03030 & 14.70 & 172.4 & 569 & 378 & 849 & 0.670 \\
\hline 900 & 0.02694 & 14.83 & 186.5 & 692 & 412 & 1030 & 0.671 \\
\hline 1000 & 0.02424 & 14.99 & 201.3 & 830 & 448 & 1230 & 0.673 \\
\hline 1100 & 0.02204 & 15.17 & 213.0 & 966 & 488 & 1460 & 0.662 \\
\hline 1200 & 0.02020 & 15.37 & 226.2 & 1120 & 528 & 1700 & 0.659 \\
\hline 1300 & 0.01865 & 15.59 & 238.5 & 1279 & 568 & 1955 & 0.655 \\
\hline 1400 & 0.01732 & 15.81 & 250.7 & 1447 & 610 & 2230 & 0.650 \\
\hline 1500 & 0.01616 & 16.02 & 262.7 & 1626 & 655 & 2530 & 0.643 \\
\hline
\end{tabular}


From: $\quad$ "George Ginther 630-840-6337" < ginther@fnal.gov>

"Russell Rucinski" <rucinski@fnal.gov>

So:1t: Tuesday, August 24, 2004 7:54 AM

Subject: Re: Cassette space pressure reliefs

\section{Hi Russ:}

Thanks for checking into this matter. 2.0 sounds more comfortable.

I did not locate additional information regarding the initial prototype tests of the seal designs, but FYI, the written cassette leak check procedure specifies pump and backfill to about 17.5 psia twice, followed by pump and backfill to $3 \mathrm{psig}$. And I am actually quite sure that 3 was used, since there are leak test sheets for each cassette showing pressure and elapsed time, and I have looked at several of them. (I also performed quite a few of these leak tests myself since I was heavily involved in the studies and repairs of the cassettes that initially leaked.)

\section{GG}

On Mon, 23 Aug 2004, Russell Rucinski wrote:

$$
>\text { George, }
$$

$>$ What I found in my notes about the cassette space gaskets was that they were tested to 2 psig at the factory, known to leak at 6 psig and blow out at 9 psig.

$$
>2
$$

ginally planned on the normal operating pressure to be 0.5 psig with the low pressure reliefs set at 1.5 psig, and the main reliefs set at a MAWP of 3.0 psig on the vessel.

$$
>
$$

$>$ Either your memory of 3 psig being the test pressure or my notes are in error. But in any case, we all will sleep better if the low pressure relief goes at 2.0 psig rather than 2.75 psig.

$>$

$>$ I will have them set at 2.0 psig. Thanks for pointing this out and paying attention.

$>$

$>$ Russ

$$
>
$$




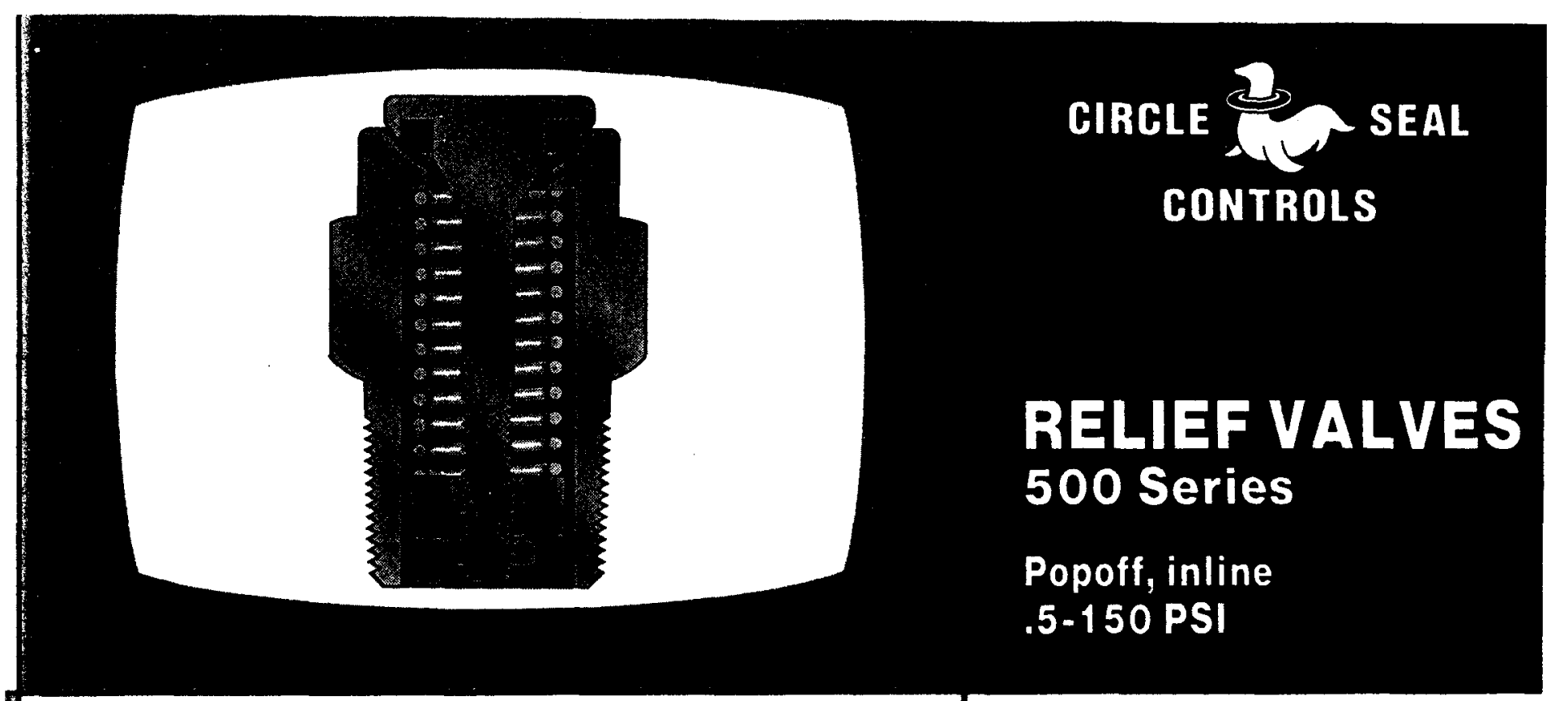

\section{OPERATING CHARACTERISTICS}

ZERO LEAKAGE - to 95-98\% of cracking pressure.

INCREASED SEALING EFFICIENCY - as pressure increases. Resilient " $Q$ " ring seal is forced against metal seat as pressure increases up to set cracking pressure.

CRACKING PRESSURE ACCURACY - Valves can be preset to required cracking pressure.

WIDE RANGE - of cracking pressures, without sacrificing flow characteristics, provided through interchangeable springs and simple adjustment. (See replacement springs and adjusting information.)

TAMPER-PROOF ADJUSTMENT - Adjustable only from inlet side for safety against tampering. Permits precise setting for the most exacting system requirements.

STICKING ELIMIMATED - Poppet head provides metal seat on low pressure side of seal, limits squeeze on resilient seal ring. Prevents water and dirt from entering valve.

LONG, MAINTENANCE-FREE SERVICE - Parts will not wear out in normal service. Overhaul, if necessary, is quickly made by replacing resilient seal.

VARIATIONS - Vent to atmosphere or inline connections, various materials.

\section{HOW IT WORKS}

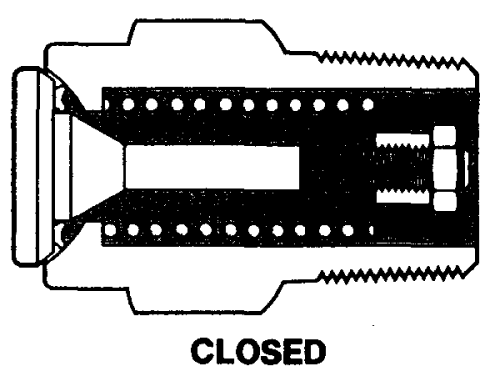

Resilient seal design prevents leakage. Sealing efficiency increases with increased pressure up to cracking pressure. Metal to metal seat on low pressure side supports spring load, prevents sticking.

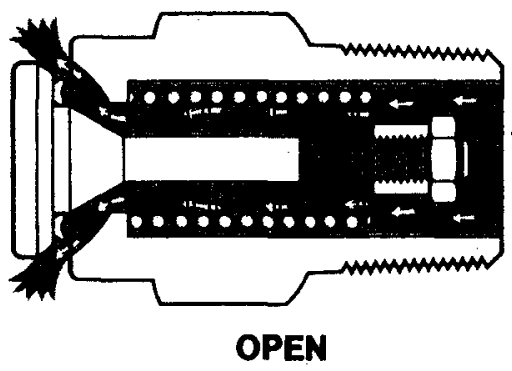

When system pressure overcomes spring force poppet opens momentarily exposing variable orifice between poppet and body to pass increasing flow with minimum pressure rise without blowdown.

\section{RESEALING}

Resilient seal automatically establishes line of contact with spherical seat. Seal provides dead tight reseal very close to cracking pressure. 


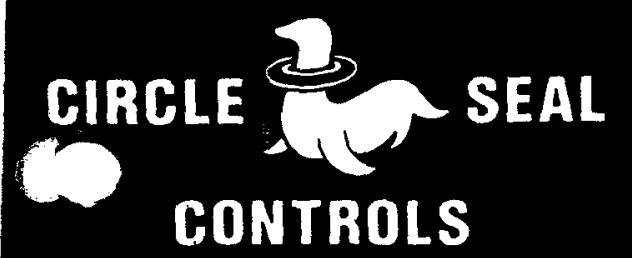

RELIEF VALVES 500 Series

Popoff, inline 5-150 PSI

TECHNICAL DATA

MATERIAL.............Body and internal parts-bar stock

SPRING ......... Stainless steel 302 or 17-7Ph

PILIENT SEAL ........ See service ommendations

OPERATING PRESSURE . . 0-200 PSI Satisfactory for vacuum applications

CRACKING PRESSURE....5-150 PSI Higher cracking pressures availableplease check with factory. (Cracking pressure is defined as $5 \mathrm{cc} / \mathrm{mi}$. with gas, except for 520 Series for which flow is 0.02 SCFM.) NOTE: See exceptions for Teflon and Silicone under Service Recommendations.

FOR INLINE VALVES:

PROOF PRESSURE . ......400 PSI BURST PRESSURE .. Above 500 PSI

ADJUSTMENT ........ Adjustment is on inlet side, and cannot be tampered with after valve is installed.

†Alpha Code is for Circle Seal internal use only.

\begin{tabular}{|c|c|c|c|}
\hline $\begin{array}{l}\text { MODEL } \\
\text { NUMBER }\end{array}$ & $\begin{array}{l}\text { O-RING } \\
\text { MATERIAL }\end{array}$ & $\begin{array}{l}\text { OPERATING } \\
\text { TEMPEAATURE }\end{array}$ & SUITABLE FOR \\
\hline 559 & Buna $N$ & $-40^{\circ}$ to $+250^{\circ} \mathrm{F}$ & $\begin{array}{l}\text { General Purpose, Air, Acetylene, Ammonia, } \\
\text { Freon 12, Hydrogen, Inert Gases }\end{array}$ \\
\hline 532 & Viton & $-20^{\circ}$ to $+400^{\circ} \mathrm{F}$ & $\begin{array}{l}\text { Aromatic Fuels, Synthetic Oils, Solvents, } \\
\text { Carbon Tetrachloride, Toluene, } \\
\text { Trichloroethylene, Steam }\end{array}$ \\
\hline 533 & Neoprene & $-40^{\circ}$ to $+250^{\circ} \mathrm{F}$ & $\begin{array}{l}\text { Oxygen, Helium, Air, Hydrogen, Carbon } \\
\text { Dioxide, Nitrogen, Acetylene }\end{array}$ \\
\hline 562 & $\begin{array}{l}\text { Ethylene } \\
\text { Propylene }\end{array}$ & $-65^{\circ}$ to $+300^{\circ} \mathrm{F}$ & Skydrol, Air, Steam \\
\hline 524 & Silicone & $-65^{\circ}$ to $+400^{\circ} \mathrm{F}$ & $\begin{array}{l}\text { Alr. Chlorinated Transformer Oil, Oxygen. Not } \\
\text { available for cracking pressures above } \\
\text { 74.9 PSI }\end{array}$ \\
\hline 520 & Teflon & $-100^{\circ}$ to $+400^{\circ} \mathrm{F}$ & $\begin{array}{l}\text { Chemically inert. Suitable for nearly all fluids. } \\
\text { Not available for cracking pressures below } \\
2.5 \text { PSI }\end{array}$ \\
\hline K520T1 & Teflon & $-320^{\circ}$ to $+165^{\circ} \mathrm{F}$ & Especially assembled and LOX cleaned \\
\hline $580 \mathrm{T1}$ & Teflon & $-320^{\circ}$ to $+165^{\circ} \mathrm{F}$ & No cryogenic processing \\
\hline
\end{tabular}

HOW TO ORDER

PART NUMBER DESIGNATION

\section{VARIATIONIDEKTIFICATION}

D-Prefixed Part Number is supplied with a cap which diverts high pressure blasts from personnel and instruments. Serves as a rain and dust shield. Increases flow capacity and facilitates manual override.

NOT RECOMMENDED FOR CRACKING PRESSURES BELOW 2 PSI

K-Cryogenic service (stainless steel valves only) (Specially manufactured, cleaned and tested for cryogenic temperatures)

\section{BASIC MODEL NUMBER}

MATERIAL

A-Aluminum T1-Stainless, 316

B-Brass

END CONNECTIONS-INLET/OUTLET

(size in 1/8")

M-Male pipe P-Female pipe

CRACKING PRESSURE-Specify setting in psi.

\begin{tabular}{|c|c|c|c|c|c|}
\hline \multicolumn{2}{|c|}{$1 M$} & \multicolumn{3}{c|}{$3 M$ thru 12M \& 4MP thru 10MP } \\
\hline CODE† & C.P. SETTWG & C.P. RANGE & CODE† & C.P. SETTING & C.P. RANGE \\
\hline A & 0.5 & $.2-9$ & A & 1 & $.5-2.4$ \\
B & 1 & $1.0-2.3$ & B & 4 & $2.5-5.9$ \\
C & 4 & $2.4-5.5$ & C & 10 & $6.0-13.9$ \\
D & 10 & $5.6-13.9$ & D & 20 & $14.0-31.0$ \\
E & 20 & $14.0-27.9$ & E & 50 & $31.0-72.9$ \\
F & 30 & $28.0-33.9$ & F & 100 & $73.0-150.0$ \\
G & 55 & $34.0-74.9$ & & & \\
H & 90 & $75.0-104.9$ & & & \\
J & 125 & $105.0-147.9$ & & & \\
\end{tabular}

\section{$\frac{2}{4}$ CIRCLE SEAL COWTROLS, ING.




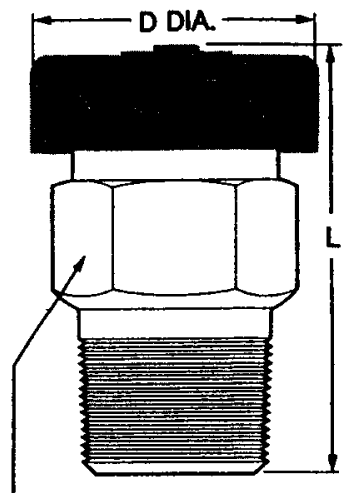

\begin{tabular}{|c|c|c|c|}
\hline $\begin{array}{c}\text { PIPE SZE } \\
\text { MALE }\end{array}$ & L & HEX & $\begin{array}{c}D \\
\text { DIA. } \\
\text { MAX }\end{array}$ \\
\hline $1 /$ & 1.14 & $1 / 2$ & .63 \\
\hline $1 / 4$ & 1.38 & $\%$ & .90 \\
\hline 3 & 1.43 & $3 / 4$ & 1.21 \\
\hline $1 / 2$ & 1.98 & 1 & 1.45 \\
\hline $3 / 4$ & 2.31 & $1 \%$ & 1.45 \\
\hline 1 & 3.16 & $11 / 2$ & 1.89 \\
\hline
\end{tabular}

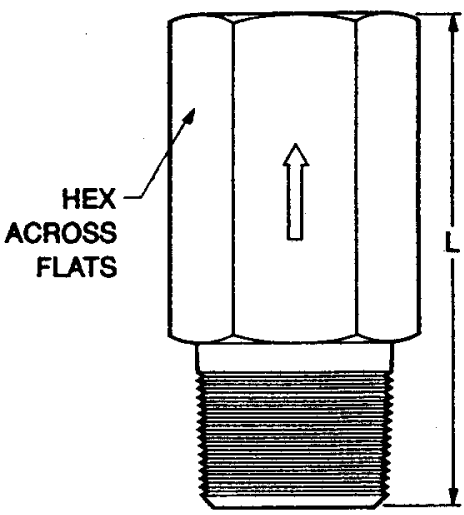

\begin{tabular}{|c|c|c|}
\hline $\begin{array}{c}\text { PIPE SIZE } \\
\text { MALE \& FEMALE }\end{array}$ & $\mathbf{L}$ & HEX \\
\hline $\begin{array}{c}1 / 4 \\
3 \\
1 / 2 \\
3 / 4 \\
1 \\
11 / 4\end{array}$ & $\begin{array}{l}1.62 \\
2.08 \\
2.34 \\
2.72 \\
3.62 \\
4.67\end{array}$ & $\begin{array}{c}3 / 4 \\
7 / 6 \\
11 / \\
11 / 4 \\
11 / 2 \\
1 \%\end{array}$ \\
\hline
\end{tabular}

- HEX ACROSS FLATS

*Complete part number must include cracking pressure. See chart on prevlous page.

\begin{tabular}{|c|c|c|c|c|c|c|}
\hline & & & 559 & 533 & 532 & 524 \\
\hline \multirow[t]{2}{*}{$\frac{2}{2}$} & POPOFF & $\begin{array}{l}1 / 6 \\
1 / 4 \\
3 / 6 \\
1 / 2 \\
3 / 4 \\
1\end{array}$ & $\begin{array}{l}559 A-1 M-* \\
559 A-2 M-* \\
559 A-3 M-* \\
559 A-4 M-* \\
559 A-6 M-\star \\
559 A-8 M-*\end{array}$ & $\begin{array}{l}533 A-1 M-* \\
533 A-2 M-* \\
533 A-3 M-* \\
533 A-4 M-* \\
533 A-6 M-* \\
533 A-8 M-*\end{array}$ & $\begin{array}{l}532 A-1 M-* \\
532 A-2 M-* \\
532 A-3 M-* \\
532 A-4 M-* \\
532 A-6 M-* \\
532 A-8 M-*\end{array}$ & $\begin{array}{l}524 A-1 M-* \\
524 A-2 M-* \\
524 A-3 M-* \\
524 A-4 M-{ }^{*} \\
524 A-6 M-{ }^{*} \\
524 A-8 M-*\end{array}$ \\
\hline & INLINE & $1 / 4$ & 559A-2MP-* & 533A-2MP- * & 532A-2MP_* & 524A-2MP- * \\
\hline \multirow{2}{*}{$\frac{g}{\frac{8}{6}}$} & POPOFF & $\begin{array}{l}1 / 6 \\
1 / 4 \\
3 / 6 \\
1 / 2 \\
3 / 4 \\
1\end{array}$ & $\begin{array}{l}\text { 559B-1M-* } \\
\text { 559B-2M-* } \\
\text { 559B-3M-* } \\
\text { 559B-4M-* } \\
559 B-6 M-* \\
559 B-8 M-*\end{array}$ & $\begin{array}{l}\text { 533B-1M-* } \\
533 B-2 M-* \\
533 B-3 M-* \\
533 B-4 M-* \\
533 B-6 M-* \\
533 B-8 M-*\end{array}$ & $\begin{array}{l}\text { 532B-1M-* } \\
532 B-2 M-* \\
532 B-3 M-* \\
532 B-4 M-* \\
532 B-6 M-* \\
532 B-8 M-*\end{array}$ & $\begin{array}{l}524 B-1 M-* \\
524 B-2 M-* \\
524 B-3 M-* \\
524 B-4 M-* \\
524 B-6 M-{ }^{*} \\
524 B-8 M-{ }^{*}\end{array}$ \\
\hline & INLINE & $\begin{array}{c}1 / 4 \\
3 / 6 \\
1 / 2 \\
3 / 4 \\
1 \\
11 / 4\end{array}$ & $\begin{array}{l}\text { 559B-2MP-* } \\
\text { 559B-3MP-* } \\
\text { 559B-4MP-* } \\
\text { 559B-6MP-* } \\
\text { 559B-8MP-* } \\
\text { 559B-10MP-* }\end{array}$ & $\begin{array}{l}\text { 533B-2MP-* } \\
\text { 533B-3MP-* } \\
\text { 533B-4MP-* } \\
\text { 533B-6MP- * } \\
\text { 533B-8MP-* } \\
\text { 533B-10MP- * }\end{array}$ & $\begin{array}{l}\text { 532B-2MP-* } \\
\text { 532B-3MP-* } \\
\text { 532B-4MP-* } \\
\text { 532B-6MP-* } \\
\text { 532B-8MP-* } \\
\text { 532B-10MP-* }\end{array}$ & $\begin{array}{l}\text { 524B-2MP-* } \\
\text { 524B-3MP-* } \\
\text { 524B-4MP-* } \\
\text { 524B-6MP-* } \\
\text { 524B-8MP-* } \\
\text { 524B-10MP-* }\end{array}$ \\
\hline \multirow[t]{2}{*}{$\begin{array}{l}0 \\
0 \\
0 \\
0 \\
0\end{array}$} & POPOFF & $\begin{array}{l}1 / 6 \\
1 / 4 \\
1 / 6 \\
1 / 2 \\
3 / 4 \\
1\end{array}$ & $\begin{array}{l}559 T 1-1 M-* \\
559 T 1-2 M-* \\
559 T 1-3 M-* \\
559 T 1-4 M-* \\
559 T 1-6 M-* \\
559 T 1-8 M-*\end{array}$ & $\begin{array}{l}533 T 1-1 M-* \\
533 T 1-2 M-* \\
533 T 1-3 M-* \\
533 T 1-4 M-* \\
533 T 1-6 M-* \\
533 T 1-8 M-*\end{array}$ & $\begin{array}{l}532 T 1-1 M-* \\
532 T 1-2 M-* \\
532 T 1-3 M-* \\
532 T 1-4 M-* \\
532 T 1-6 M-* \\
532 T 1-8 M-*\end{array}$ & $\begin{array}{l}524 T 1-1 M-* \\
524 T 1-2 M-* \\
524 T 1-3 M-* \\
524 T 1-4 M-* \\
524 T 1-6 M-* \\
524 T 1-8 M-*\end{array}$ \\
\hline & INLINE & $\begin{array}{l}1 / 4 \\
1 / 2 \\
3 / 4\end{array}$ & $\begin{array}{l}\text { 559T1-2MP-* } \\
\text { 559T1-4MP-* } \\
\text { 559T1-6MP-* }\end{array}$ & $\begin{array}{l}\text { 533T1-2MP-* } \\
\text { 533T1-4MP- } \\
\text { 533T1-6MP- * }\end{array}$ & $\begin{array}{l}\text { 532T1-2MP-* } \\
\text { 532T1-4MP-* } \\
\text { 532T1-6MP-* }\end{array}$ & $\begin{array}{l}\text { 524T1-2MP-* } \\
\text { 524T1-4MP-* } \\
\text { 524T1-6MP-* }\end{array}$ \\
\hline
\end{tabular}

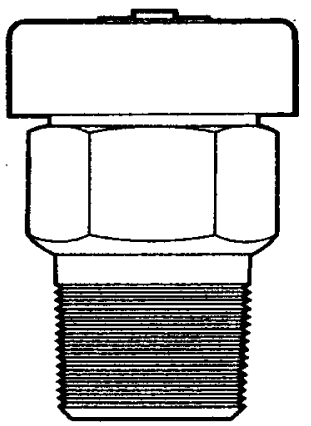

For ASME code valve, available in $1 / 4$ inch size only. Add ASME after valve number. For operation details see ASME Valve catalog sheet, Form Number CSP-366L.

\begin{tabular}{|c|c|c|c|c|c|c|c|}
\hline C.P. RANGE & $1 M / 2 M P$ & 2M/3MP & C.P. RANGE & 3M/4MP & AM/GMP & GM/8MP & 8M/10MP \\
\hline $\begin{array}{c}0.2-0.9 \\
1.0-2.3 \\
2.4-5.5 \\
5.6-13.9 \\
14.0-27.9 \\
28.0-33.9 \\
34.0-74.9 \\
75.0-104.9 \\
105.0-147.9\end{array}$ & $\begin{array}{l}22335-0.5 \\
22335-1 \\
22335-4 \\
22335-10 \\
22335-20 \\
22335-30 \\
22335-55 \\
22335-90 \mathrm{PH} \\
22335-125 \mathrm{PH}\end{array}$ & $\begin{array}{l}22336-0.5 \\
22336-1 \\
22336-4 \\
22336-10 \\
22336-20 \\
22336-30 \\
22336-55 \\
22336-90 \mathrm{PH} \\
22336-125 \mathrm{PH}\end{array}$ & $\begin{array}{c}.5-2.4 \\
2.5-5.9 \\
6.0-13.9 \\
14.0-31.0 \\
31.1-72.9 \\
73.0-150.0\end{array}$ & $\begin{array}{l}10362-1 \\
10362-4 \\
10362-10 \\
10362-20 \\
10362-50 \\
10362-100 \mathrm{PH}\end{array}$ & $\begin{array}{l}10462-1 \\
10462-4 \\
10462-10 \\
10462-20 \\
10462-50 \\
10462-100 \mathrm{PH}\end{array}$ & $\begin{array}{l}10662-1 \\
10662-4 \\
10662-10 \\
10662-20 \\
10662-50 \\
10662-100 \mathrm{PH}\end{array}$ & $\begin{array}{l}10845-1 \\
10845-4 \\
10845-10 \\
10845-20 \\
10845-50 \\
10845-100 \mathrm{PH}\end{array}$ \\
\hline
\end{tabular}

**Springs for each valve slze are interchangeable. The Cracking Preceure range can be changed by replacing the apring with one covering the deatred range. 


\section{TYPICAL FLOW CURVES}

Use the curves below to determine the pressure increase over cracking pressure for a given cracking pressure, flow rate and valve size. Interpolate between the curves for cracking pressures not shown.

\section{SERIES}
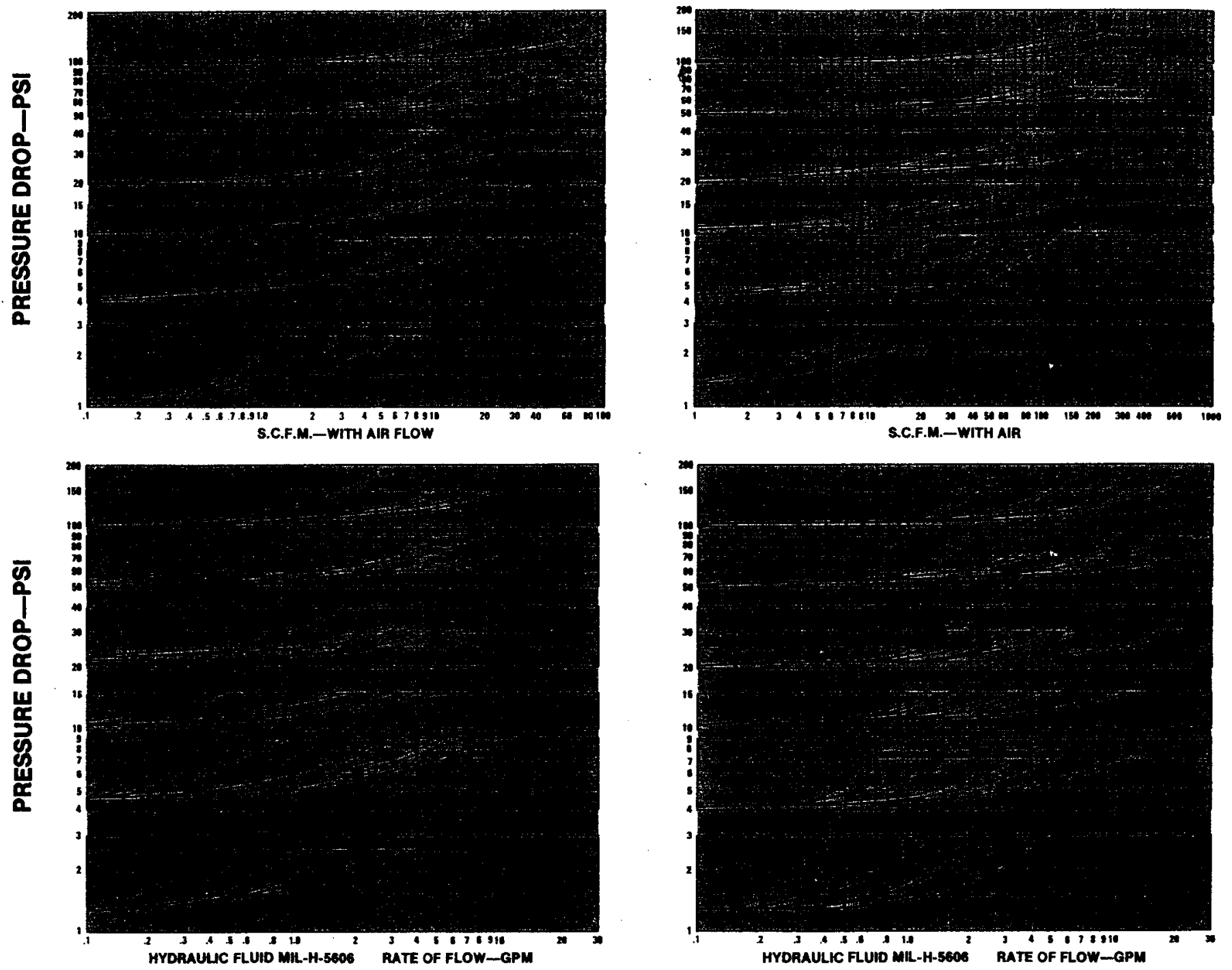

\section{D500 SERIES}
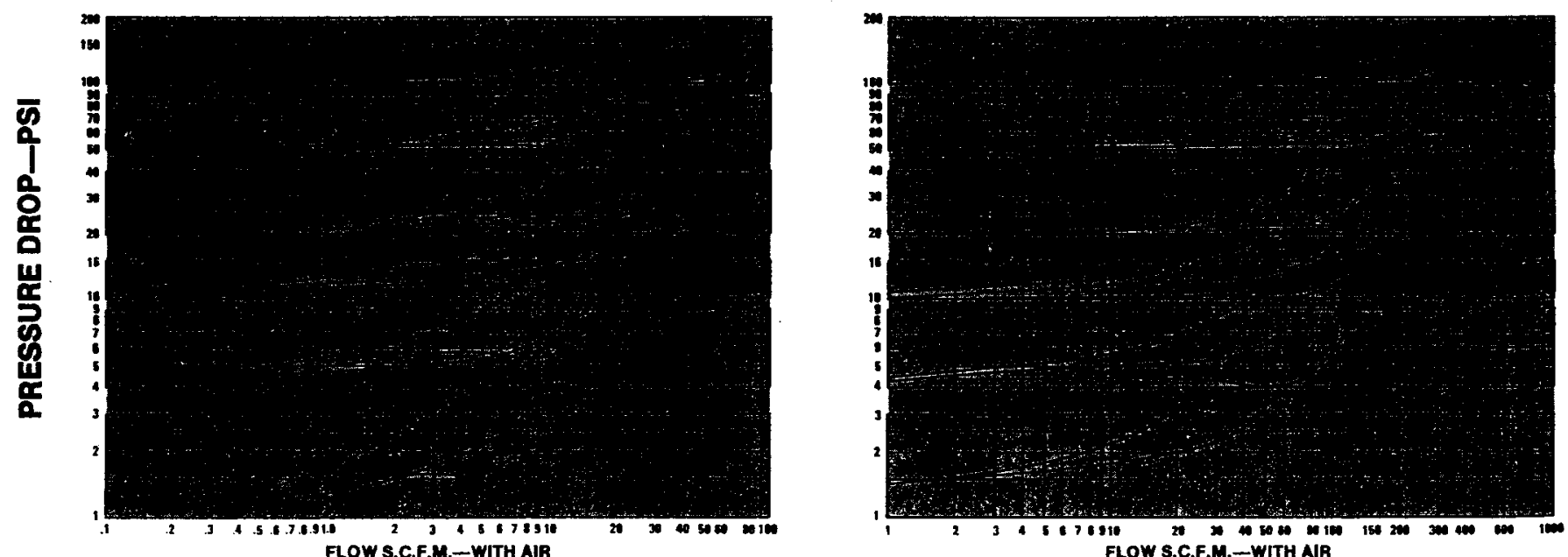

\section{SA GRELE SEAL BONTROLS, INE.}

2301 WARDLOW CIRCLE

CORONA. BOX 3300 


\begin{tabular}{|c|c|}
\hline \multirow{5}{*}{ 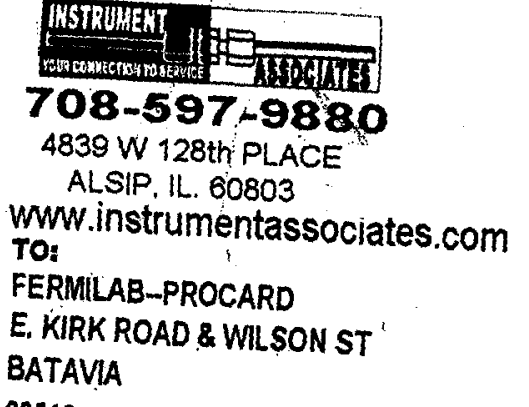 } & $\begin{array}{l}\text { CUSTOMER PO\# } \\
\text { PRN } 533312\end{array}$ \\
\hline & $\begin{array}{l}\text { CUST PN } \\
\text { 559B-4MP-2 }\end{array}$ \\
\hline & $0 \pi / 1$ \\
\hline & $\begin{array}{l}\text { DESCRPPTION } \\
\text { RELIFEE VALVE }\end{array}$ \\
\hline & $\begin{array}{l}\text { ITEM NUMBER } \\
\text { 559B-4MP-2 }\end{array}$ \\
\hline
\end{tabular}

\begin{tabular}{|c|c|}
\hline \multirow{5}{*}{ 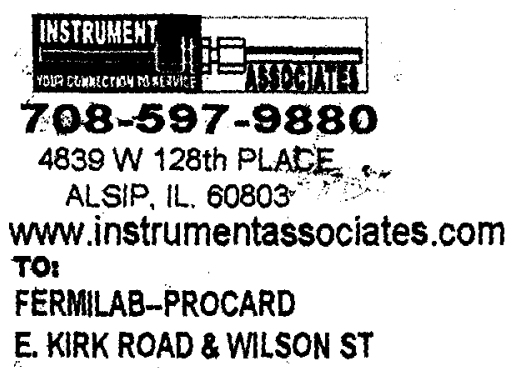 } & $\begin{array}{l}\text { CUSTOMER PO\# } \\
\text { PRN\#\$53312 }\end{array}$ \\
\hline & $\begin{array}{l}\text { CSTPN PN } \\
559 \mathrm{~B}-4 \mathrm{MP}-2\end{array}$ \\
\hline & OTY: 1 \\
\hline & $\begin{array}{l}\text { DESCRAPTION } \\
\text { RELIEE VALVE }\end{array}$ \\
\hline & $\begin{array}{l}\text { TEM NUMBER } \\
\text { 559B-4MP-2 }\end{array}$ \\
\hline
\end{tabular}

60510 


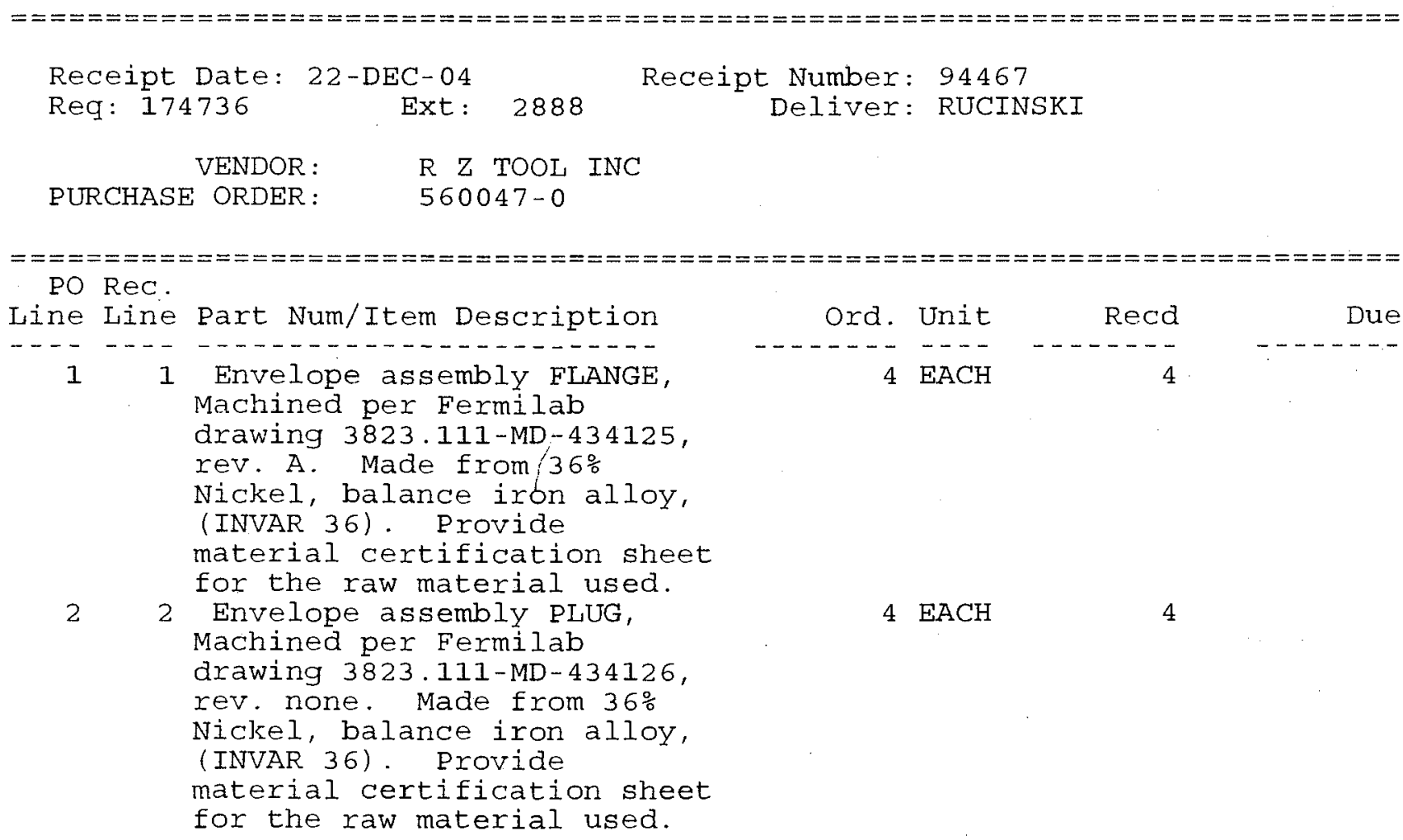

$4 \mathrm{EACH} \quad-1$

4 


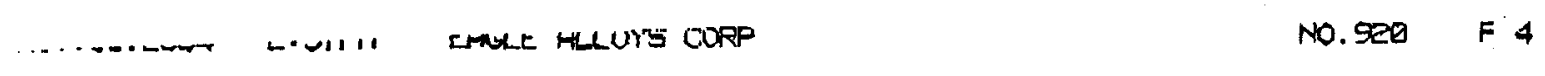

\section{EAGLE ALLOYS CORP.}

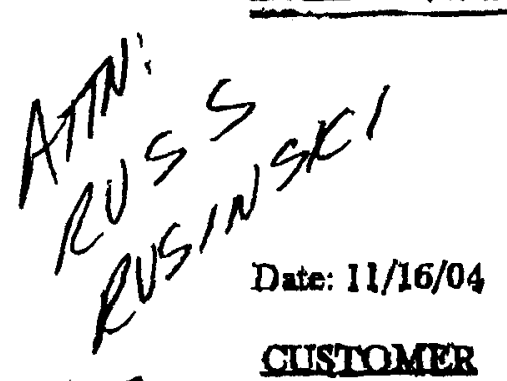

10t2
CTISTOMNRR

RZ Tool inc.

117 West Park $C_{t}$ Talbot, TN. 87877

\section{MATERIAL TEST REPORTS}

CISTOMMRR ORDERNO.

Verbal - Samantha

\section{OURNNo.t!}

$11-0893$

Wo Certify that

Dencription

Invar 36

$1 / 2^{\prime \prime}$ Thk $\times 1.402^{\prime \prime}+125 \times 10,764^{14}+125$
Oxal Xeidut

4 Pas.

\section{Cartarmuto}

Heat 1076040615 ASTM F-1604 UNS Kagd IS
CHENTCLE ANAYYSXS

NII $\quad 36.77$

12. 0.01

MNi 0.43

ci $\quad 0.01$

SI: 0,12 .

P. $\quad 0,003$

CR: $\quad 0.02$

s: $\quad 0.001$

CO: $\quad 0.02$

TH: $<0.01$

MG: 0.02

FI: Bdunt

\section{MECRENTCAL PROPENTLS}

\section{BXPDNASS HRB 68}

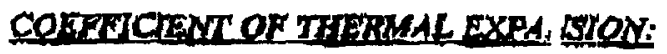

$1.1 \mathrm{col} / \mathrm{cm}{ }^{\circ} \mathrm{C} \times 10(-6) \times .00^{\circ} \mathrm{C}$

$2.0 \mathrm{co0} / \mathrm{cm}{ }^{\circ} \mathrm{CX} 10(-6) \odot 50^{\circ} \mathrm{C}$

$2.5 \mathrm{~cm} / \mathrm{am}{ }^{\circ} \mathrm{C} X 10(-6) ; 00{ }^{\circ} \mathrm{C}$

$6.9 \mathrm{~cm} / \mathrm{cm}$ "C X 10(6) : $50^{\circ} \mathrm{C}$

9.2 andord $20 \times 10(-6)$ (1) 30.0

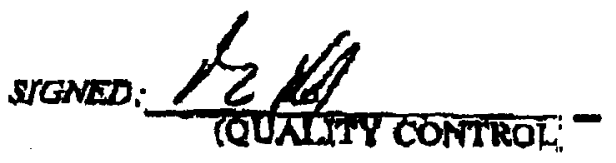




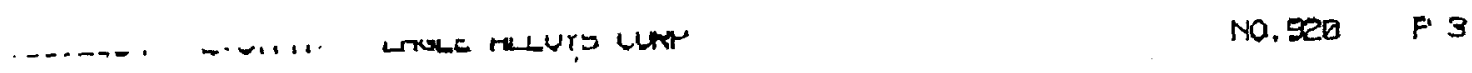

\section{EAGLE ALLOYS CORP.}

117 West Park Ct Talbot, TN, 87877

\section{MATGRLAL TEST REPORTS}

Date: 11/16/04

CUSTCOMER

RZ Tool Inc.

We Cerrtify that

Deacrintion

Invar $\mathbf{3 6}$

ir" Thk $x 4.347^{\prime \prime}+125 \times 18.659^{4}+.125$
CURTOMARR ORDERNO

Verbal - Semantha
QUtRva.tt

$11-0833$

\section{CHEMTCLL ANALYSTS}

NI: $\quad 36.77$ AL: 0.01

MN: 0.43 C. 0.01

SI: $\quad 0.12 \quad P_{i} \quad 0.003$

CR. $0.02 \quad$ s: $\quad 0.001$

co: $0.02 \quad \pi:<0.01$

MG: $0.02 \quad$ RE; Belunce

ZR: 0.01

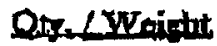

4 Pes.
Conformate

Heat: 1978040015

ASTM F-1684 UNS KQSI 03

\section{MECHANICAL PROPERTISS}

\section{HARDNESS: HRB 68}

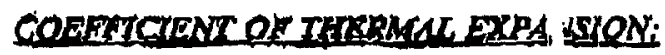

$1.1 \mathrm{~cm} / \mathrm{cm}{ }^{\circ} \mathrm{C} \times 10(-6) \circ ! 00^{\circ} \mathrm{C}$

$2.0 \mathrm{~cm} / \mathrm{cm}^{\circ} \mathrm{C} \times 10(4) \oplus .50^{\circ} \mathrm{C}$

$2.5 \mathrm{~cm} / \mathrm{cm}{ }^{\circ} \mathrm{CX} 10(-) ; 00{ }^{\circ} \mathrm{C}$

$6.9 \mathrm{cro} / \mathrm{am}{ }^{\circ} \mathrm{C} \times 10(-0) \mathrm{ec}: 50^{\circ} \mathrm{C}$

$9.2 \mathrm{~cm} / \mathrm{sm}{ }^{\circ} \mathrm{C} X 10(0) \bigcirc+50^{\circ} \mathrm{C}$

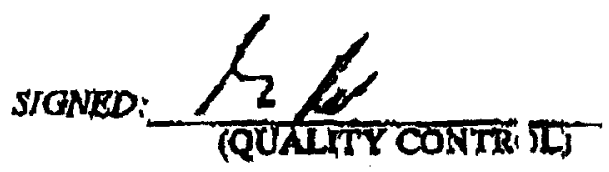




\section{독 Fermilab}

$3 / 2 / 2005$

\section{M.I.C.E. 2 slot Cryocooler cryostat}

\section{Pressure Testing Permit ${ }^{*}$}

Type of Test: $\quad[\sqrt{ }]$ Pneumatic - helium

Test Pressure: 4 psig + vacuum $=18.7$ psia. $\quad(112 \%$ MAWP $)$

Maximum Allowable Working Pressure: 2 psig + vacuum $=16.7$ psia.

Items to be Tested: Stagnant cassette gas helium space.

Location of Test: D-Zero Ass'y Building ___ Date: March $3^{\text {rd }}, 2005$

Hazards Involved: None, very little store energy. (134 ft-lbs, 182 joules stored energy).

Safety Precautions Taken: Test area is sufficiently isolated from incidental traffic.

Special Conditions or Requirements: Vacuum Jacket will be evacuated to $<1$ torr. A helium mass spectrometer leak detector will be monitoring the vacuum space for leaks..

Test Coordinator: Russ Rucinsk ZumallA 2 Dept/Date PPD/MD/D0 Ops 3/1/2005

Division/Section Safety Officer Haivis the fech Dept/Date ESH 312/05 Dept/Date PPD $3 / 2 / 05$

Results CASSETTE SPACE HELD 4.0 PSIG + FULL VACUUM. FOR MORE THAN 10 minUTES WHEN ISOLATED. THERE IS A SMALL O.RING LEAK TO VACUUM SPACE. $\approx(4 \mu / \mathrm{MIN} R I S E)$ THAT NEEDS TO BE FIXED. VACUUM PRESSURE $10 \times 10^{-3}$ TORR TO Witnese Pualle Pre PPD/Mo/DF Dept/Date $3-3-05$ (Safety Officer or Designee) Games Jagan ppolmo/ oq $100 \times 10^{-3}$ TOCR DURING TEST. CRYOSTAT PASSED PRESSURE TEST.

\footnotetext{
${ }^{*}$ Must be signed by division/section safety officer and division/section head prior to conducting test. It is the responsibility of the test coordinator to obtain signatures. 
FERMILAB ENGINEeRING NOTE

Pressure test of M.l.c.e.

CRYDCOOLER CRYOSTAT.

\begin{tabular}{|l|l|} 
SEERILLCATEGOAY & PAGE \\
\hline
\end{tabular}

SUBJECT

Russ RuelNok,

\begin{tabular}{|c|c|}
\hline DATE & $-28-05$ \\
\hline
\end{tabular}

OPERATING PRESSURE 1.5 PSI \pm .5 PSi

Relief pressure $=2$ psis.

cassette gaskets good to 3 psia?

PROPOSE TEST PRESSURE $=4$ PSIS.

$(18.7$ PSIA $)$

$\%$ overpressure $=\frac{4+14.7}{2+14.7}(100)=112 \%$

Volume $=0.3 \mathrm{Ft}^{3}$

STORED ENERGY CALCULATION (REF. BN H5-5060-17) PRESSURE SAFETY COURSE.

$$
\begin{aligned}
& E=\frac{P_{1} V_{1}}{K-1}\left[1-\left(\frac{P_{2}}{P_{1}}\right)^{\frac{k-1}{k}}\right] \times C \\
& 8.33 \times 10^{-2} \\
& =134 \text { ft-l6s STORED ENERGY. } \\
& =182 \text { Joveses }
\end{aligned}
$$




\section{Energy of Gas System}

Gas confined under high pressure is like a hungry tiger in a cage. If it should suddenly escape in a populated area, someone would probably be injured. When a gas-pressure vessel fails, it propels jagged vessel fragments out in all directions.

To better understand the energy released when a container of gas ruptures, imagine that a $10-\mathrm{ft}^{3}$ vessel of nitrogen fails at 6000 psig. Compare this to the $4.62 \mathrm{MJ}\left(3.42 \times 10^{6} \mathrm{ft}-\mathrm{lb}\right)$ of energy released when $1 \mathrm{~kg}(2.2 \mathrm{lb})$ of TNT is detonated. The energy of the gas, assuming isentropic expansion, is ${ }^{1}$

$U_{\text {gas }}=\frac{P_{1} V_{1}}{\gamma-1}\left[1-\left(\frac{P_{2}}{P_{1}}\right)^{\frac{\gamma-1}{\gamma}}\right]$

where

$P_{1}=$ container pressure

$\mathrm{P}_{2}=$ atmospheric pressure

$\gamma=\frac{c_{p}}{c_{v}}=1.41$ for $N_{2}$

This expression as written, will yield an energy value in joules if pressure and volume units are in megapascals (Mpa), and cubic centimeters (cc), respectively. For units of $\mathrm{ft}-\mathrm{lb}$ psi, and $\mathrm{ft}^{3}$, a conversion factor to these units is required as

$$
\begin{aligned}
& \mathrm{U}_{\text {gas }}= \\
& \begin{aligned}
\left(8.33 \times 10^{-2}\right) \frac{6015 \times 10 \times 1728}{1.4-1}\left[1-\left(\frac{14.7}{6015}\right)^{\frac{1.41-1}{1.41}}\right] \\
\quad=1.74 \times 10^{7} \mathrm{ft-lb} \text { or } 23.6 \mathrm{MJ}
\end{aligned}
\end{aligned}
$$

The weight of equivalent explosive is

$$
\frac{1.74 \times 10^{7}}{3.42 \times 10^{6}}=5.1 \mathrm{~kg}
$$

which is over $11 \mathrm{lb}$. of TNT.

A liquid confined under high pressure is also a potential safety hazard. However, for systems of comparable volume and pressure the amount of stored energy in the liquid case will be considerably less than that contained in the gas. The energy involved in the sudden failure of a liquid filled vessel may be conservatively determined from

$\mathrm{U}_{\mathrm{liq}}=\frac{1}{2}\left(\frac{\mathrm{P}_{1}^{2} \mathrm{~V}}{\mathrm{~B}}\right)$

where

$$
B=\text { Liquid bulk modulus }
$$

Some typical bulk modulus values are

$$
\begin{aligned}
& B=300,000 \text { psi for water } \\
& B=225,000 \text { psi for oil } \\
& B=630,000 \text { psi for glycerin }
\end{aligned}
$$

Were the container above filled with water,

$$
\begin{aligned}
U_{\text {liq }} & =1 / 2\left(\frac{6015^{2} \times 10 \times 1728}{30000 \times 12}\right) \\
& =8.683 \times 10^{4} \mathrm{ft.lb} .
\end{aligned}
$$

explosive in this case the weight of equivalent

$$
\frac{8.683 \times 10^{4}}{3.42 \times 10^{3}}=25.4 \mathrm{gms} \mathrm{TNT}
$$




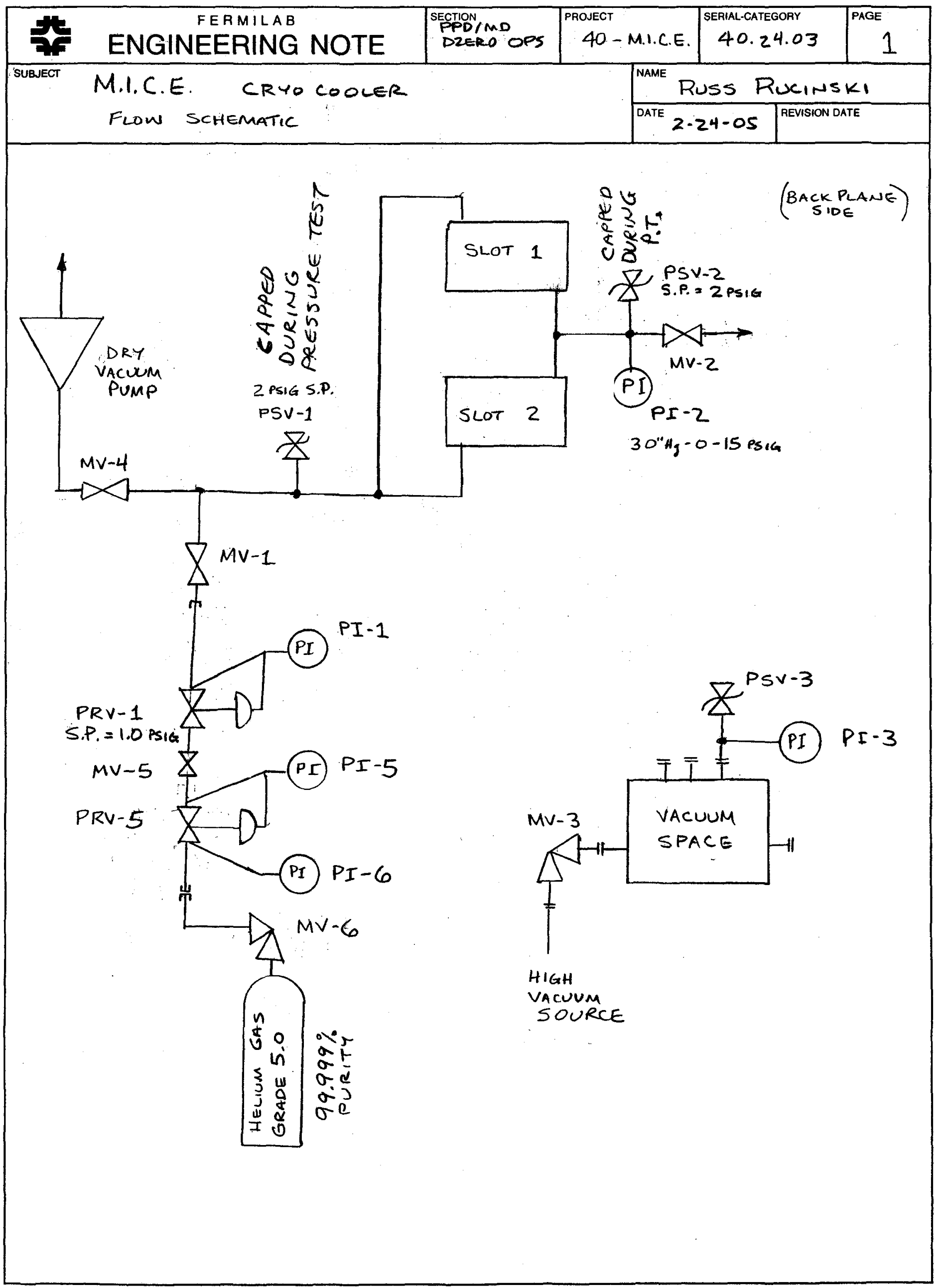




\section{Tag \# Description}

MV-1 Cassette space helium supply valve

MV-2 Cassette space purge or vent valve

MV-3 Insulating vacuum isolation valve

MV-4 Cassette space vacuum pump out valve

MV-5 Gas helium supply regulator isolation valve

MV-6 Gas helium cylinder valve

$\mathrm{Pl}-1 \quad$ Cassette space helium supply pressure indicator

$\mathrm{Pl}-2$ Cassette space pressure indicator

$\mathrm{PI}-3 \quad$ Insulating vacuum pressure indicato

PI-5 Reguiated helium cylinder supply pressure

PI-6 Helium cylinder pressure

PRV-1 Cassette space helium supply pressure regulator

PRV-5 Helium supply cylinder pressure regulator

PSV-1 Cassette space pressure relief valve

PSV-2 Cassette space pressure relief valve

PSV-3 Vacuum space pressure relief valve

\section{Manufacturer}

VAT

Victor Equipment company

not applicable

US Gage

Hastings

US Gage

US Gage

Victor Equipment company

Circie Seal Controls, inc.

Circle Seal Controls, inc.

Circle Seal Controls, Inc.

\section{Model}

26332 KA01

$n / a$
$n / a$

19267
DV-6

TS-450B

559B-4MP-2

$559 \mathrm{~B}-4 \mathrm{MP}-2$

532B-3M-8

\section{Setting or range}

\section{$n / a$}

$n / a$

$n / a$
$30^{\mathrm{n}} \mathrm{Hg}$ vacuum - 0 - $15 \mathrm{psig}$ $0-1$ Torr
0 - 60 psig (0-0.4 Mpa) range 0-4000 psig (0-28 Mpa) range

set 1.0 psig
set 10 psig

2 psig $(0.115 \mathrm{MPa})$

2 psig $(0.115 \mathrm{MPa})$

8 psig $(0.156 \mathrm{MPa})$
Pressure Rating

Size

$2 \mathrm{~atm}$.

KF40

60 psi min.

n/a

1/4" NPT

$\mathrm{n} / \mathrm{a}$

15 psig

$30 \mathrm{psi}$

90 psi min.

4000 psig min.

1/4" NPT

1/4" NPT $1 / 4^{4}$ NPT

3000 psi

CGA 580

$400 \mathrm{psi}$ 1/2" MNPT

$400 \mathrm{psi} \quad 1 / 2^{\mathrm{N}} \mathrm{MNPT}$

$200 \mathrm{psi} \quad 3 / 8^{\prime \prime} \mathrm{NPT}$ 


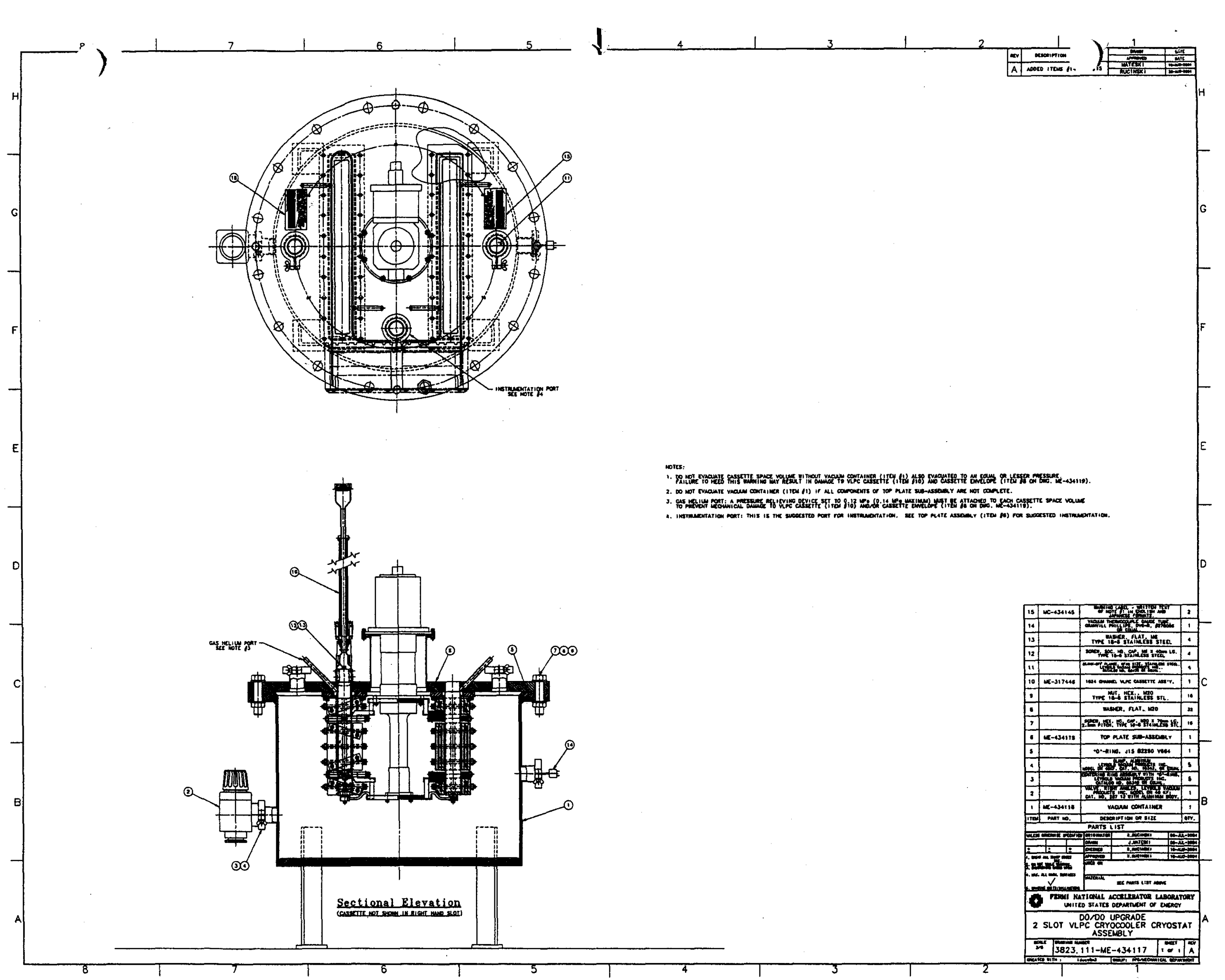




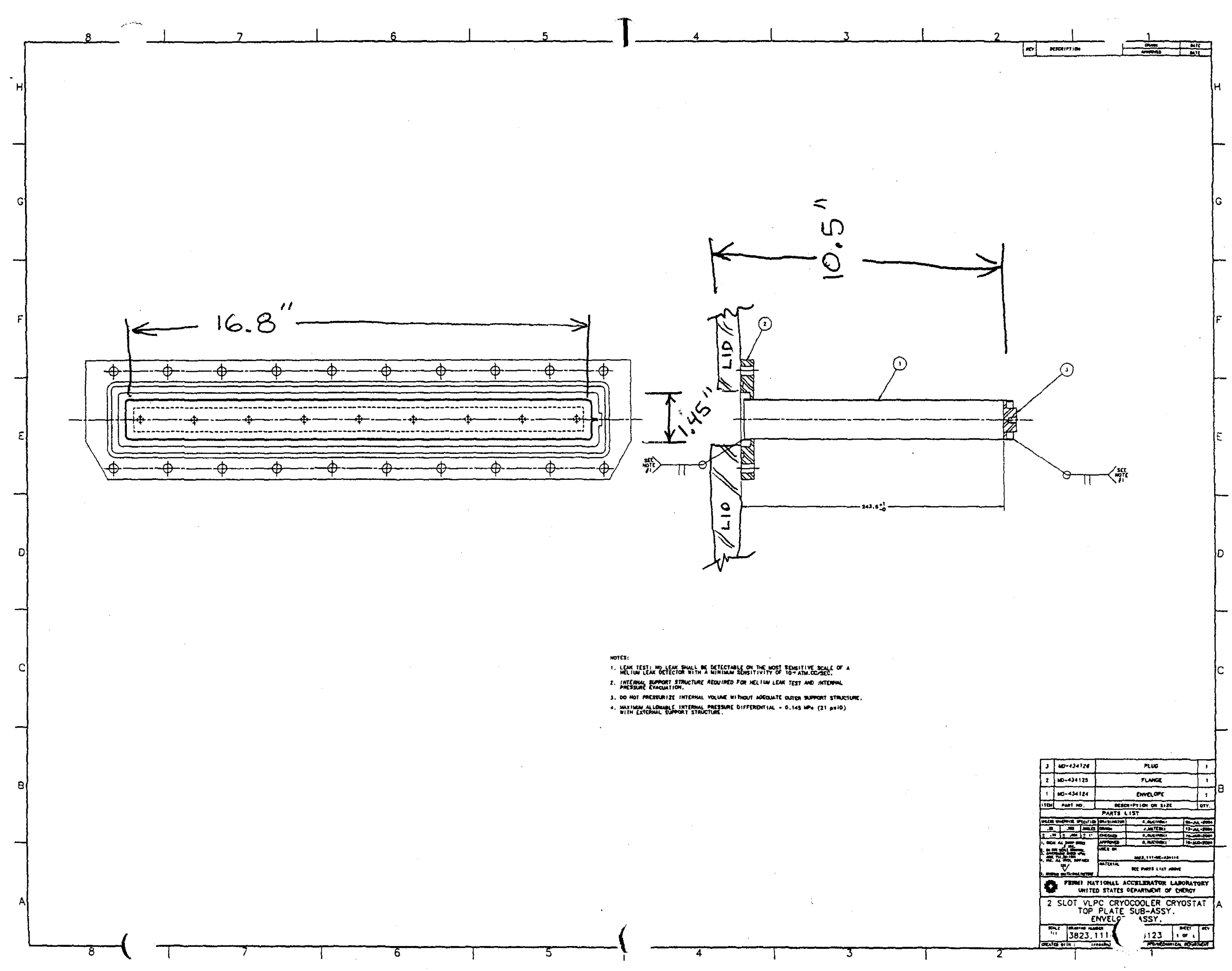


MICE pressure Test

of cassetTE SPACE R.RUCINSKI

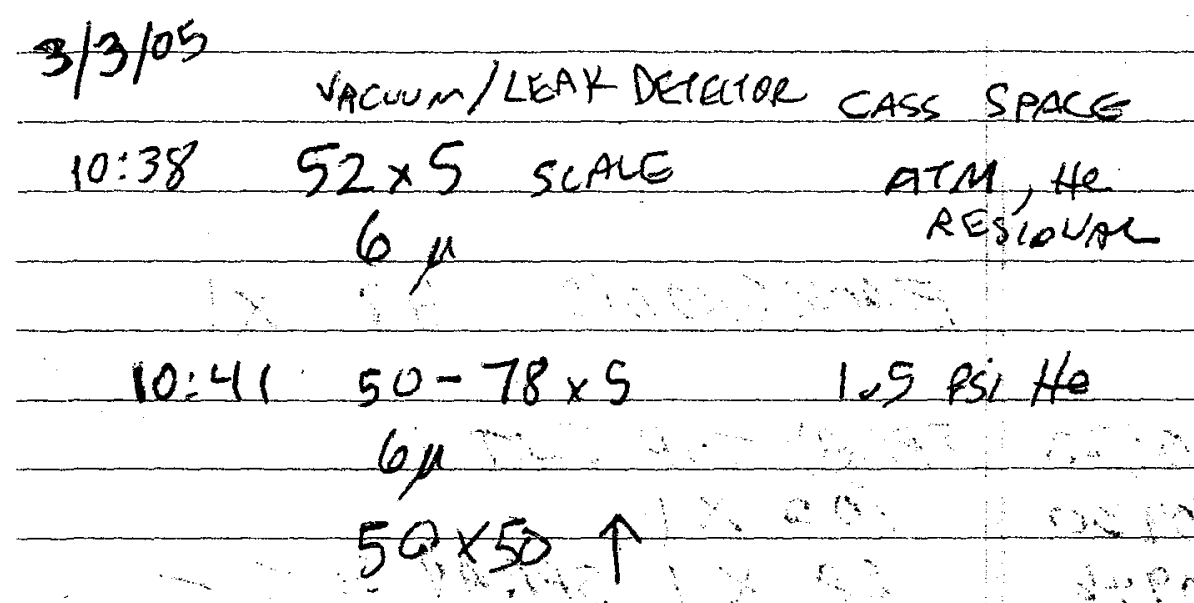

10:44 VALVED OFF LEAK DETGCTOR 14. WE HAV A SMAU He lGAK $10: 45$ 1SOUACO VACUM PUMPS. 10.472 $2.2 \mathrm{Psi}$ $10=49.32 \mu$ $10=54 \quad 52 \mu$ 1.5 PSI LEAK ON

$$
R \nabla R=4 \pi / \mathrm{mc}
$$$$
\text { - BLANKS }
$$$$
>_{00} \cos s
$$

$10.5966 \mu \quad 3.2$ psi clampisa

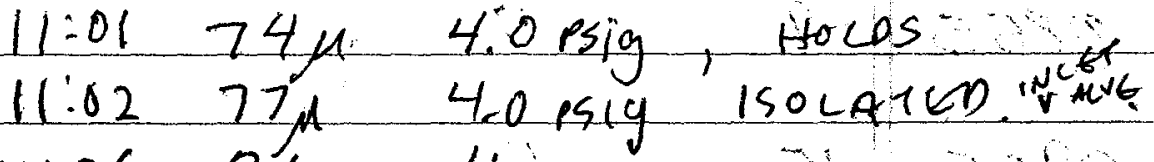

$$
\begin{aligned}
& 11: 06 \quad 86 \% \quad 4.0 \text { psi6. } \\
& 11: 10 \text { 95. } 4.0 \mathrm{ks}
\end{aligned}
$$

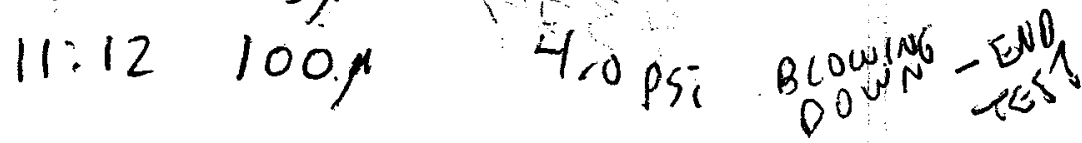




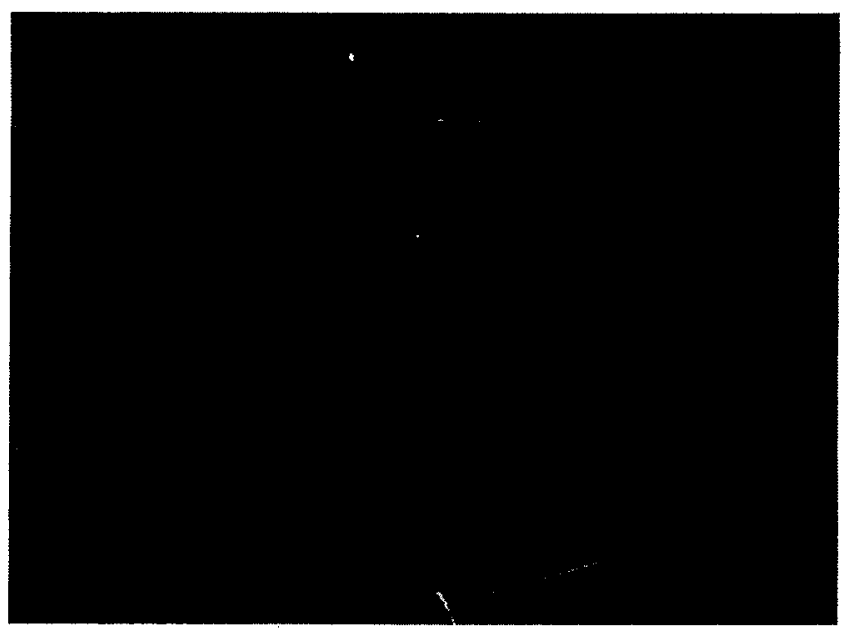




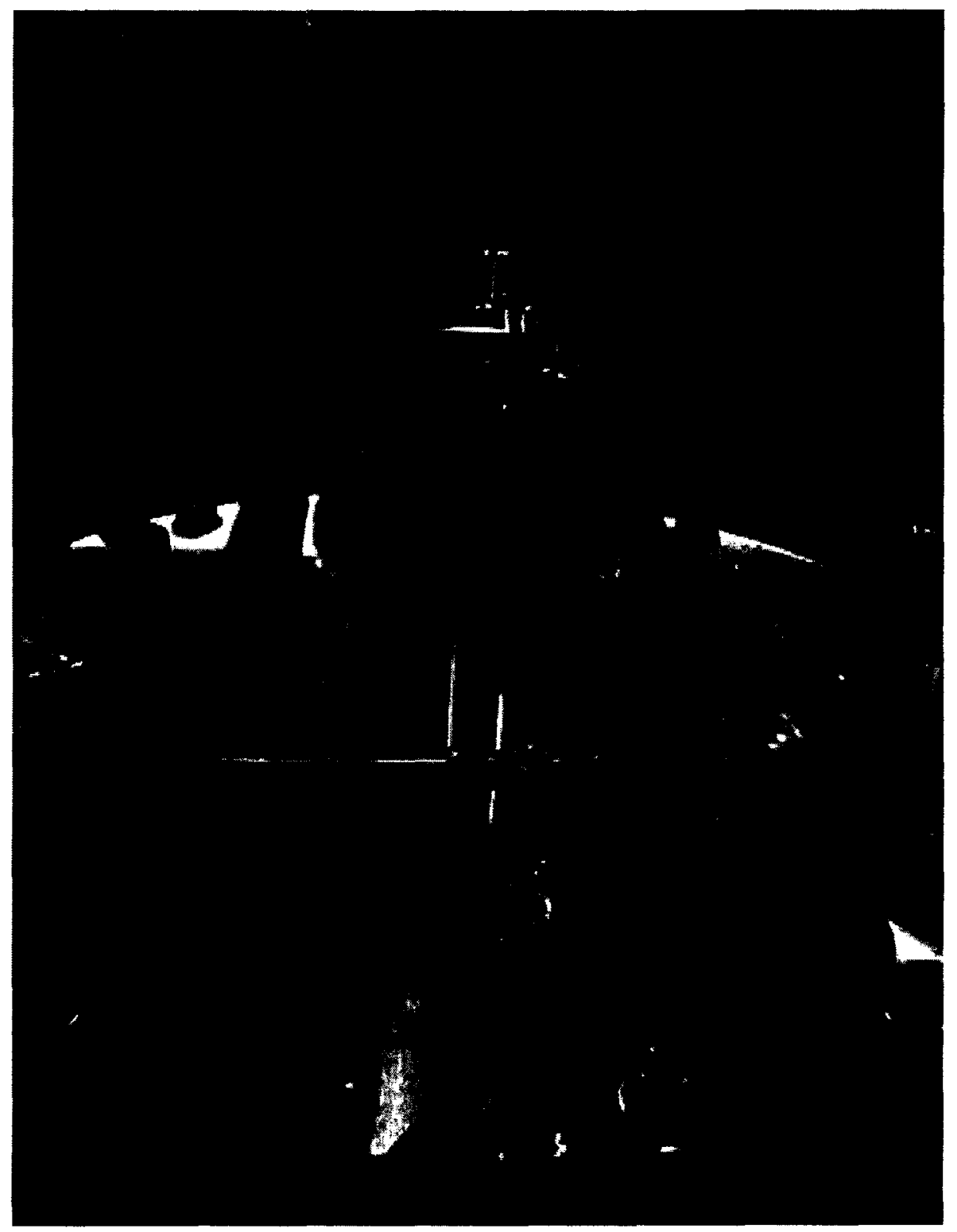


